\title{
Karolina Lachowska
}

Uniwersytet Wrocławski

ORCID: 0000-0003-3659-6785

\author{
Marcin Pielużek
}

Uniwersytet Wrocławski

ORCID: 0000-0001-9508-3627

\section{Sztuka uliczna jako źródło wiedzy na temat współczesnych społeczeństw - propozycja i weryfikacja metody badawczej}

\begin{abstract}
Streszczenie
Główny cel artykułu to zaprezentowanie i weryfikacja podejścia badawczego, możliwego do zaimplementowania $w$ badaniach street artu na gruncie nauki o komunikacji społecznej i mediach. Dzięki skoncentrowaniu się $w$ trakcie analiz na czterech wymiarach: przestrzeni (gdzie), temporalności (kiedy), reprezentacji (kto) i przekazie (co), możliwe jest pozyskanie kompleksowej wiedzy na temat kluczouych aktorów, propagowanych idei, postulatów i wartości, nakreślenia głównych linii podziału, punktów zapalnych, punktów odniesienia, ikon i postaci symbolicznych. Sztukę uliczną traktujemy tu jako formę społeczno-politycznego komentarza na poziomie lokalnym, przestrzeń miejską jako kanał, a poszczególne przejauy street artu medium komunikacji. Użyteczność propozycji metodologicznej zostanie zueryfikowana na bazie korpusu 195 zdjęć przedstawiających różnorodne formy sztuki ulicznej tworzonej w trakcie protestów w Chile zrobionych przez autorów u grudniu 2019 roku.
\end{abstract}

Słowa kluczowe: sztuka uliczna, komunikacja społeczna, media, metoda badawcza.

\section{Street art as a source of knowledge about contemporary societies - a proposal of a research method and its verification}

\begin{abstract}
The article's main aim is to present and verify the research approach that can be implemented in street art research in the field of social communication and media science. By focusing analysis on four dimensions - space (where), temporality (when), representation (who) and message (what), it is possible to obtain comprehensive knouledge about key social actors, propagated ideas, postulates and values, and to delineate the main dividing lines, points of reference, icons and symbolic characters. We treat street art as a form of socio-political commentary at the local level, urban space as a channel, and individual manifestations of street art as a medium of communication. The methodological proposal's usefulness will be verified based on a corpus of 195 photos showing various forms of street art created during the protests in Chile, taken by the Authors in December 2019.
\end{abstract}

Keywords: street art, social communication, media, research proposal. 


\section{Wprowadzenie}

Różnorodne formy sztuki ulicznej stały się częścią współczesnego krajobrazu miejskiego. Pojawiają się $\mathrm{w}$ formie komercyjnych i niekomercyjnych, wielkopowierzchniowych murali, graffiti, uszelkiego rodzaju plakatów i ulepek. Wszystkie te odmiany dostarczają badaczom cennej wiedzy. Pokazują między innymi stosunek władz i mieszkańców do takiej formy przekazu oraz sposoby interakcji odbiorców z różnymi przejawami street artu. Traktując sztukę uliczną jako medium, a przestrzeń miejską jako kanał komunikacji, prace te dają możliwość realizacji badań z zakresu komunikacji wizualnej, semiotyki, semantyki oraz identyfikacji współczesnych subkultur i wszelkich innych aktorów pozostawiających swoje ślady w przestrzeni miejskiej. Mimo wielu interesujących perspektyw badawczych współczesna sztuka uliczna u niewielkim zakresie jest lokowana w centrum zainteresowań polskich badaczy, w szczególności tych zajmujących się komunikacją społeczną i mediami. Kiedy przeglądamy publikacje autorstwa rodzimych badaczy, pojawiają się prace odnoszące się do polskiego graffiti z lat osiemdziesiątych XX wieku. Wóuczas ta forma komunikacji była jedną z form oporu wobec komunistycznej władzy, symbolem rozkwitu kultury alternatyunej w Polsce $^{1}$, przejawem sztuki ludowej ${ }^{2}$ lub różnorodnych form komunikacyjnej subuersji ${ }^{3}$. Temat ten jest podejmowany także przez przedstawicieli sztuk pięknych, prawników, socjologów czy też pedagogów. W zakresie szeroko rozumianej komunikacji społecznej prace koncentrują się $\mathrm{w}$ dużej mierze na sztuce ulicznej, jako narzędziu zarządzania i promocji miasta lub jej wpływie na wizerunek ${ }^{4}$.

W niewielkim zakresie są podejmowane analizy street artu w sposób całościouy począuszy od warstuy semantycznej i semiotycznej prac, uuzględniając powiązania z miejscem, w którym są zlokalizowane, czasem ich poustawania czy też autorstwem. Wieloaspektowa analiza sztuki ulicznej pozwala na pozyskanie cennej wiedzy na temat idei, alternatywnych narracji, wartości i tożsamości różnych społeczności. W szczególności dotyczy to grup marginalizowanych, nie mających dostępu do mainstreamowych mediów. Jak przekonuje Louis Holscher, murale są specyficznymi „gazetami

${ }^{1}$ E.C. Chabros, Polskie graffiti lat osiemdziesiatych $w$ świetle relacji jego twórców, „Pamięć i Sprawiedliwość" 2011, nr 10/1(17), s. 211-230.

2 Zob. R. Ciarka, Napisy na murach i etnografia wspótczesnego miasta, „Polska Sztuka Ludowa” 1990, nr 2, s. 33-34.

${ }^{3}$ Zob. W. Frydrych, B. Misztal, A. Couderq, Pomarańczowa Alternatywa: rewolucja Krasnoludków, Fundacja „Pomarańczowa Alternatywa”, Warszawa 2008; M. Bryła, Sztuka ulicy jako bunt wobec zastanej rzeczywistości - anarchistyczna walka z systemem na przykładzie Polski, „Inskrypcje. Półrocznik” 2020, R. VIII, z. 1(14), s. 139-147.

4 Zob. P.M. Statucki, Jak badać murale z perspektywy socjologicznej? Przykład Łodzi, „Człowiek i Społeczeństwo” 2009, t. XLVIII, s. 107-122; M. Kaczmarska, Graffiti kontra murale. Intencje twórcy a recepcja społeczna sztuki ulicznej [w:] Ulice, Centra, Peryferie, red. S. Hryń, D. Juruś, Oficyna Wydawnicza AFM, Kraków 2017, s. 37-52; B. Paliś, Mural jako środek w kreowaniu wizerunku przestrzeni miejskiej [w:] Czy obrazy rządzą ludźmi, red. A. Kampka, A. Kiryjow, K. Sobczak, Wydawnictuo SGGW, Warszawa 2017, s. 102-116; A. Niemczyk, B. Paliś, Mural jako narzędzie promocji turystycznej miasta, „Przedsiębiorczość i Zarządzanie” 2017, T. XVIII, z. 8, cz. III, s. 169-181. 
na ścianach", w których na niewielkiej przestrzeni jest skondensowane bogactwo informacji ${ }^{5}$. Stuierdzenie to pozostaje aktualne nie tylko w kontekście murali, lecz także całej, szeroko rozumianej sztuki ulicznej.

Główny cel artykułu to zaprezentowanie i weryfikacja podejścia badawczego, możliwego do zaimplementowania w badaniach street artu na gruncie dyscypliny nauk o komunikacji społecznej i mediach. Koncepcja ta została opisana przez Birte Vogela i innych - badaczy zajmujących się stosunkami międzynarodouymi, dla których graffiti i inne przejawy sztuki ulicznej okazały się cennym źródłem wiedzy na temat społeczeństu funkcjonujących $w$ strefach konfliktu ${ }^{6}$. Koncentruje się ona na czterech kluczowych wymiarach: przestrzeni, temporalności, reprezentacji i przekazie (gdzie, kiedy, kto i co). Ostatni aspekt dodatkowo można podzielić na mniejsze subkategorie, które w konsekwencji pozwalają na identyfikację kluczouych problemów, punktów zapalnych, linii podziału, alternatywnych narracji, ikonicznych postaci i wydarzeń, kluczouych dla danej społeczności. Choć autorzy tej koncepcji ograniczają się do wąskiego aspektu - sztuki ulicznej w strefach konfliktu, to naszym zdaniem propozycja ta jest o wiele bardziej uniwersalna i równie skuteczna w analizach prac w społecznościach funkcjonujących w okresie braku konfliktu. Co więcej, jest ona możliwa do zastosowania niezależnie od stopnia wiedzy na temat analizowanej społeczności.

\section{Sztuka uliczna jako oferta medialna}

Nasze rozważania lokujemy na gruncie teorii konstruktywistyczno-systemowej ${ }^{7}$. Za Niklasem Luhmannem przyjmujemy, że system społeczny składa się z określonych subsystemów komunikacyjnych (polityki, gospodarki, prawa itd.), które generują komunikację, korzystając z unikalnego dla siebie kodu ${ }^{8}$. Przyjmując zatem, że każdy z subsystemów wytwarza własne kody społeczne i typowe dla niego semantyki, znaczenia poszczególnych elementów semiotycznych będą zależały od tego, co oznaczają one dla danego subsystemu. Tym samym różne subsystemy, przetwarzając dane treści na podstawie własnych kodów, mogą interpretować te same treści u sposób odmienny9. Uwaga ta jest o tyle ważna w kontekście podejmowanego tematu, że niemożliwe jest

${ }^{5}$ M. Delgado, K. Barton, Murals in Latino Communities: Social Indicators of Community Strengths, „Social Work” 1998, t. 43, nr 4, s. 346.

${ }^{6}$ B. Vogel, C. Arthur, E. Leppb, D. O’Driscollc, B.T. Haworth, Reading socio-political and spatial dynamics through graffiti in conflict-affected societies, „Third World Quarterly” 2020, t. 41, nr 12, s. 2148-2168.

7 Zob. chociażby: Radykalny konstruktywizm. Antologia, red. B Balicki [i in.], Wydaunictwo Gajt, Wrocław 2010; Konstruktywizm w badaniach literackich. Antologia, red. E. Kuźma, A. Skrendo, J. Madejski, Towarzystwo Autorów i Wydawców Prac Naukouych Universitas, Kraków 2006; N. Luhmann, Systemy społeczne: zarys ogólnej teorii, przeł. M. Kaczmarczyk, Zakład Wydawniczy Nomos, Kraków 2007; M. Fleischer, Media w perspektywie konstruktywizmu, „2K - Kultura i Komunikacja” 2005, nr 1-2, s. 10-33.

${ }^{8}$ N. Luhmann, op. cit.

${ }^{9}$ H. De Berg, Communication as Challenge to Systems Theory. „Canadian Review of Comparative Literature" 1997, s. 145-146. 
uskazanie jednej możliwej interpretacji danych prac, a wszystkie interpretacje są równorzędne ${ }^{10}$.

Systemowe podejście wymaga jednocześnie stosowania „patrzenia systemowego”. Ervin Laszlo definiuje ten koncept następująco:

Patrzenie systemowe polega na ujmowaniu świata w kategoriach układów zintegrowanych relacji. [...] Oznacza to myślenie w kategoriach faktów i zdarzeń, osadzonych w kontekście peunych całości, które stanowią zintegrowane układy o swoistych własnościach i relacjach ${ }^{11}$.

W wyniku tak rozumianych procesów komunikacyjnych wyłaniają się „modele rzeczywistości”, wytuarzane na bazie wiedzy kolektywnej członków danych społeczności. „System rozróżnień budujący ramy kategorialne modelu rzeczywistości musi być truale powiązany ze społeczną semantyką i ze społecznie sankcjonowanymi emocjami i normami"12.

Poszczególne przejauy sztuki ulicznej rozumiemy więc za Siegfriedem J. Schmidtem jako oferty medialne definiowane następująco:

Poprzez odpowiednie połączenie materiałów semiotycznych (znaki językowe, obrazy itd.) aktanty wytwarzają oferty medialne, które przekazują innym, oczekując „rozumienia”. [...] Żeby wytuorzyć ofertę medialną posiadającą zdolność do społecznego mechanizmu oczekiwania oczekiwań na operacje semiotyczne, czyli kierować się na właściwe konwencje lub uwzględnić wiedzę zawartą $\mathrm{w}$ common-sense ${ }^{13}$.

Wykorzystywany przez nas termin sztuki ulicznej obejmuje wiele różnorodnych form funkcjonujących w przestrzeni miejskiej, będących wyrazem artystycznych, społecznych, kulturowych i politycznych praktyk określonych społeczności w danych przestrzeniach miejskich. Obejmuje on zatem treści malowane za pozwoleniem władz, jak również prace poustające nielegalnie. Od podstawowych wizualnie form w postaci tagów, haseł malowanych na murach, po bardziej rozbudowane wizualnie i semiotycznie graffiti, plakaty i murale. Ignorujemy podział na prace uznawane za przejaw

${ }^{10}$ Humberto Maturana określa to mianem „obiektywności wziętej w nawias”. Tak rozumiana obiektywność „powoduje akceptację tego, że istnienie [tutaj interpretacja - przyp. aut.] jest uyodrębnione poprzez rozróżnienie [dokonywane - przyp. aut] przez obserwatora, że jest tyle dziedzin istnienia, ile jest rodzajów rozróżnień, których dokonuje obserwator". Stoi to u kontrze do obiektywności bez nawiasu, która zakłada istnienie niezależnego obserwatora, odgórnie określającego prawdę. Obiektyuność tę cechuje redukcyjność, „ponieuaż pociąga za sobą rzeczywistość jako pojedynczą i ostateczną dziedzinę zdefiniouaną przez niezależne istnienie" H. Maturana, Ontologia obserwacji. Biologiczne podstawy samoświadomości i fizykalna dziedzina egzystencji [w:] Radykalny konstruktywizm. Antologia, op. cit., s. 85.

${ }^{11}$ E. Laszlo, Systemowy obraz świata, przeł. U. Niklas, Państwowy Instytut Wydawniczy, Warszawa 1978, s. 40.

12 J.S. Schmidt, Kultura a kontyngencja: nauki obserwatora, „2K - Kultura i Komunikacja” 2004, nr 1, s. 2-5.

${ }^{13}$ J.S. Schmidt, Konstruktywizm jako teoria mediów [w:] Konstruktywizm w badaniach literackich. Antologia, red. E. Kuźma, A. Skrendo, J. Madejski, Touarzystuo Autorów i Wydauców Prac Naukowych Universitas, Kraków 2006, s. 317. 
sztuki i akty wandalizmu, jaki często pojawia się $w$ literaturze $e^{14}$, jak również aspekt legalności projektów, wychodząc z założenia, że każdy przejaw sztuki ulicznej jest komunikacyjnie relewantny. Aczkolwiek należy podkreślić, że niejednokrotnie kuestia wandalizmu czy nielegalności jest również kontekstowo ważna jako przejaw oporu ${ }^{15}$ czy aktywizmu $^{16}$. Nasze analizy ograniczają się jednocześnie do oddolnych przejawów sztuki ulicznej. Jak przekonywał Bill Rolston, w przeciwieństuie do tworzonych odgórnie prac, będących odpowiedzią na naciski lub oczekiwania władz i służąc jako kanał dystrybucji oficjalnej propagandy, oddolna aktywność cechuje się wolnością wyrażania poglądów, najczęściej pozostających w kontrze do oficjalnych treści, będących głównie głosem grup marginalizowanych lub wykluczonych z oficjalnego dyskursu i/lub nieposiadających swojej reprezentacji w mediach głównego nurtu ${ }^{17}$. Jak dodaje Stella Grotouska, są one przejawem „uczestnictwa w kulturze, ukierunkowanego na kuestie opresji i dominacji” ${ }^{18}$, wskazując na „problemy i bolączki, zajmujące określone społeczeństua"19.

Sztukę uliczną traktujemy więc za Rolstonem jako medium pośredniczące między nadawcami i odbiorcami, zapewniające wykluczonym lub pozbawionym dostępu do mediów głównego nurtu społecznościom możliwość dotarcia do szerszego audytorium i partycypacji w dyskursie ${ }^{20}$. Równocześnie jest ona mechanizmem włączającym inne jednostki do partycypacji w dyskursie. Egzemplifikacją tego procesu jest chociażby Kair w dobie Arabskiej Wiosny. Jak uskazuje Nicholas Mirzoeff, w trakcie okupacji placu Tahrir ruchy społeczne wykorzystywały do swojej walki różnorodne formy wizualne. Graffiti nie miało okazji rozwinąć się przed 2011 rokiem w przestrzeni miejskiej pozostającej pod kontrolą władz. Arabska Wiosna stała się impulsem do odzyskiwania przestrzeni publicznej i wykorzystywania graffiti jako narzędzia do dyskusji, docierając do odbiorcóu pozbawionych dostępu do medióu głównego nurtu. „Sztuka graffiti [...] do czasu zamachu stanu przez generała Sisi [...] napędzała debatę polityczną i stymulowała

${ }_{14}$ Zob. M.A. Gomez, The writing on our walls: Finding solutions through distinguishing graffiti art from graffiti vandalism, „University of Michigan Journal of Law Reform” 1993, nr 26(3), s. 633-707; M. Halsey, A. Young, The meanings of graffiti and municipal administration, „Australian \& New Zealand Journal of Criminology” 2002, nr 35(2), s. 165-186.

${ }_{15}$ Zob. J. Ferrell, Urban Graffiti: Crime, Control, and Resistance, „Youth \& Society” 1995, nr 27(1), s. 73-92; J. Ferrell, Crimes of Style: Urban Graffiti and the Politics of Criminality, Northeastern University Press, Boston 1996; G. Ortiz van Meerbeke, B. Sletto, Graffiti takes its own space, "City: analysis of urban trends, culture, theory, policy, action” 2019, nr 23(3), s. 366-387.

16 Zob. D Mitchell, The Right to the City: Social Justice and the Fight for Public Space, The Guilford Press, New York 2003.

17 B. Rolston, jHasta La Victoria!: Murals and Resistance in Santiago, Chile, „Identities” 2011, nr 18(2), s. 113-114.

18 S. Grotouska, „Street Art” i „Guerilla Marketing” jako próby tworzenia przestrzeni publicznej, „Studia Humanistyczne AGH” 2012, nr 11(3), s. 12.

19 M. Bryła, Sztuka ulicy jako bunt wobec zastanej rzeczywistości..., op. cit., s. 141.

${ }^{20}$ B. Rolston, „H Hasta La Victoria!: Murals..., op. cit., s. 114. 
wyobrażenia o nowych drogach rozwoju kraju ${ }^{21 "}$. Graffiti okazało się także kluczowe dla komunikacji w trakcie jaśminowej rewolucji w Tunezji. Całkowita kontrola władz nad mediami tradycyjnymi i społecznościowymi sprawiła, że tylko „graffiti, hasła malowane na ścianach, drzwiach, a czasem na chodnikach i przestrzeniach publicznych stały się istotnymi środkami efektywnej komunikacji”22.

Lokalizacja prac w ogólnodostępnej przestrzeni miejskiej i odpowiednia ekspozycja przekłada się na potencjalnie duży zasięg prezentowanych treści. Tym samym w momencie dostrzeżenia określonej pracy istnieje szansa na przejęcie naszej uwagi (interpelacji) przez obraz. Termin „interpelacja” wywodzący się z języka francuskiego „łączy ze sobą znaczenie zuracania się do kogoś u sposób guałtowny z określonym żądaniem, wypytywania o tożsamość oraz uzbudzania w kimś echa”23. W kontekście komunikacji wizualnej Marita Sturken i Lisa Carturight, zapożyczając znaczenie terminu od Louisa Althussera ${ }^{24}$, rozumieją interprelację jako sposób, w jaki obrazy, dźuięki, media audiouizualne nie tylko przejmują naszą uwagę, lecz także nakazują uznać siebie jako podmiot, do którego jest adresouana treść. Z interpelacją jednak będziemy mieli do czynienia jedynie wówczas, kiedy zostaniemy bezpośrednio „dotknięci” przez obraz, dostrzeżemy siebie jako członka grupy, do której dany obraz „przemawia”, nawet jeśli znaczenie dla jednej osoby będzie zupełnie inne niż dla innej. Innymi słowy „być interpelowanym przez obraz to wiedzieć, że obraz jest przeznaczony «dla ciebie»", przy czym nie ma znaczenia, czy jako odbiorcy zgadzamy się z jego przekonaniami i wartościami²5.

\section{Miasto jako przestrzeń komunikacyjna i protestu}

Miasto jest specyficzną formą życia zbiorowego łączącą ze sobą aspekty filozofii, urbanistyki, socjologii i ekonomii. Robert Park twierdził, że jest ono „najspójniejszą i, ogólnie rzecz biorąc, najbardziej udaną próbą, jaką kiedykolwiek podjął człowiek w przekształcaniu świata, w którym żyje, zgodnie z głosem swojego serca. Jednakże

\footnotetext{
${ }^{21}$ N. Mirzoeff, Jak zobaczyć świat, przeł. Ł. Zaremba, Wydawnictuo Karakter, Kraków-Warszawa 2016, s. 272.

${ }^{22}$ N. Miladi, Alternative fabrics of hegemony: City squares and street graffiti as sites of resistance and interactive communication flow, ,Journal of African Media Studies” 2015, nr 7, s. 134.

${ }^{23}$ R. Mańko, Koncepcja interpelacji ideologicznej a krytyczny dyskurs o prawie, „Archiwum Filozofii Prawa i Filozofii Społecznej" 2014, nr 1, s. 45.

${ }^{24}$ Althusser pisał o tym w sposób następujący: ,[...] ideologia «działa» lub «funkcjonuje» w ten sposób, że «rekrutuje» podmioty spośród jednostek (rekrutuje je uszystkie), albo «przekształca» jednostki w podmioty (przekształca uszystkie), poprzez tę ścisłą operację, którą nazwaliśmy interpelacją, a którą można sobie wyobrazić na wzór najbanalniejszego wezwania policyjnego (albo nie) wszystkich czasów: «Hej, ty tam!». Jeżeli zakładamy, że owa wyobrażona scenka teoretyczna dzieje się na ulicy, to interpelowana jednostka odwraca się. Poprzez prosty fizyczny zurot o 180 stopni, staje się ona podmiotem. Dlaczego? Ponieważ rozpoznała, że interpelacja była skierowana «ułaśnie» do niej, i że «to właśnie ona była interpelowana» (a nie kto inny)". Cyt. za R. Mańko, Koncepcja interpelacji..., op. cit., s. 45.

${ }_{25}$ M. Sturken, L. Cartwright, Practoces of Looking. An Introduction to Visual Culture, Oxford University Press, New York-Oxford 2001, s. 53.
} 
jeżeli miasto jest śuiatem stuorzonym przez człowieka, to jest to też świat, w którym jest on dotąd zmuszony żyć" ${ }^{26}$. Przyjmując zatem za Aleksandrem Wallisem, że jest to system „złożony z dwóch organicznie powiązanych na zasadzie sprzężeń zurotnych, lecz autonomicznych podsystemów - urbanistycznego i społecznego" ${ }^{27}$, należy założyć, że relacje zachodzące między społeczną a fizyczną naturą miasta, czyli sposób dostosouyuwania i uykorzystywania przestrzeni miejskiej, z jednej strony wynika z zachodzących zmian społeczno-politycznych, z drugiej - z poczucia prawa obywateli do miast. W konsekwencji rozbudowywany jest repertuar funkcji, jakie miasta mogą pełnić (np. miejsce do życia, zabawy, pracy). W tej pracy skoncentrowano się na mieście jako miejscu protestów. Zatem za istotne uznano oba przedstawione aspekty: urbanistyczny - zaułaszczenie przestrzeni miejskiej przez protestujących, zmianę i dostosowywanie rytmu życia miasta do protestów, a także podejście do miasta jako sieci społecznych, w tym tworzenia się i uspółpracy społeczności terytorialnych i różnorodnych organizacji ${ }^{28}$.

Według Macieja Kowalewskiego sposób, w jaki zostały skonstruowane miasta, daje techniczne możliwości do organizowania wielotysięcznych zgromadzeń (np. aleje, place, rynki). W tym miejscu wystarczy przypomnieć sobie demonstracje w Warszawie, Hongkongu, Waszyngtonie czy Londynie. Miejsca, które są wybierane na protest, nie są przypadkowe. Z jednej strony uwzględniana jest tradycja protestu w danym miejscu (np. Krakouskie Przedmieście w Warszawie, Champs Elysees w Paryżu czy Trafalgar Square w Londynie). Powiązanie w społecznej świadomości konkretnej lokalizacji i protestu przekłada się na symbolikę tego miejsca. Z drugiej strony protestuje się w określonych miejscach, żeby zdezorganizować codzienne życie obywateli (np. poprzez głośność, uciążliwość, zablokowanie głównych arterii ${ }^{29}$. Przejęcie kontroli nad miastem ma jednocześnie wymiar symboliczny, na przykład przejęcie stolicy = przejęciu władzy ${ }^{30}$. Miasta dają dodatkowo poczucie bezpieczeństua i anonimowości protestującym, a ze uzględu na zagęszczenie mieszkańców ułatwiają organizowanie się i funkcjonowanie grup partyzanckich ${ }^{31}$.

Miasta są więc „areną protestów”. Za Magdaleną Tanderą przyjęto, że protest to „publiczny wyraz niezgody lub niezadowolenia oraz towarzyszące temu manifestacje posiadanego potencjału działania, w celu przeciudziałania pogłębianiu się niepożądanych stanów dysproporcji w zasobach kapitału materialnego i symbolicznego"32.

${ }^{26}$ R.E. Park, On Social Control and Collective Behavior, University of Chicago Press, Chicago 1967, s. 23.

${ }^{27}$ A. Wallis, Socjologia przestrzeni, przeł. I. Drozdouska-Broering, Niezależna Oficyna Wydawnicza, Warszawa 1990, s. 45.

${ }^{28}$ T. Sozański, Sieć społeczna [w:] Encyklopedia socjologii PWN, Wydawnictwo Naukowe PWN, Warszawa 2002, s. 28.

${ }^{29}$ M. Kowaleuski, Miasto jako arena protestu, „Konteksty Społeczne” 2013, nr 1, s. 2.

30 J. Gugler, The Urban Character of Contemporary Revolutions, „Studies in Comparative International Development" 1982, t. 17, nr 2, s. 62-69.

${ }_{31}$ M. Kowaleuski, Protest miejski. Przestrzenie, tożsamości i praktyki niezadowolonych obywateli miast, NOMOS, Kraków 2016, s. 22.

${ }_{22}$ M. Tendera, Protest jako mechanizm równoważenia nierówności spotecznych, „hultura i Społeczeństwo" 2013, nr 2, s. 130. 
Cechuje się tym, iż „ma miejsce głównie poza zinstytucjonalizowanymi kanałami politycznymi; obejmuje przedstawienie decydentom politycznym roszczeń, dotyczących różnych kwestii polityki publicznej, których częściowa lub całkowita realizacja upływa znacząco na rezultaty tej polityki [...]”33. Kluczowa dla tych rozważań jest propozycja Verty Taylor i Nelli Van Dyke. Przedstawiają one protest jako „obszary kontestacji (sprzeciuru), w których wykorzystuje się ciała, symbole, tożsamości, praktyki i dyskursy, w celu przeprowadzenia lub poustrzymania zmian w obrębie zinstytucjonalizowanej władzy"34. Przyjmujemy zatem, że protest nie ogranicza się stricte do zgromadzenia. Obejmuje także symboliczne formy protestu, przejmowania przestrzeni i uwagi w formie graffiti oraz innych przejawów sztuki ulicznej. Protest coraz częściej znajduje swoją kontynuację $\mathrm{w}$ internecie, który $\mathrm{w}$ znacznym stopniu ułatuia znalezienie grup o podobnych poglądach, sprzeciwiających się konkretnym działaniom/instytucjom, a także ułatuia koordynowanie protestów, ustalenia planu działań na poziomie zarówno lokalnym, jak i globalnym. Również pojawiająca się u trakcie protestów sztuka uliczna trafia do internetu, stając się nie tylko „rezeruuarem pamięci”, lecz także źródłem konstruowania transmedialnych narracji w rozumieniu Henry'ego Jenkinsa ${ }^{35}$.

\section{Tło protestów w Chile}

Nieoficjalnie protesty u Santiago rozpoczęły się 7 października 2019 roku skoordynowaną akcją (¡Evade!) uczniów szkół średnich, która polegała na nieuiszczaniu opłat za transport miejski ${ }^{36}$. Była to odpowiedź na podniesienie cen biletów o 30 peso $^{37}$ $(15 \text { groszy })^{38}$. Według Rodrigo Bootha z Uniwersytetu w Chile w protestach nie chodziło jednak o ceny biletów komunikacji miejskiej. Protesty były bowiem efektem

${ }^{33}$ M. Kowalewski, Protest miejski. Przestrzenie..., op. cit., s. 11.

${ }^{34}$ V. Taylor, N. Van Dyke „Get up, Stand up”: Tactical Repertoires of Social Movements [w:] The Blackwell Companion to Social Movements, red. D.A. Snow, S.A. Soule, H. Kriesi, Blackuell Publishing Ltd, Hoboken 2004, s. 268.

${ }_{35}$ Zob. H. Jenkins, Kultura konwergencji. Zderzenie starych i nowych mediów, przeł. M. Bernatowicz, M. Filiciak, Wydawnictwa Akademickie i Profesjonalne, Warszawa 2007.

${ }^{36}$ A. Baeza, Evasión masiva de alumnos del Instituto Nacional en el Metro termina con denuncia en Fiscalía y medidas de contención, Latecera, https://www.latercera.com/nacional/ noticia/evasion-masiva-alumnos-del-instituto-nacional-metro-termina-denuncia-fiscalia-medidas-contencion/857409/ (dostęp: 6.04.2021).

37 Już przed wprowadzeniem zmian ceny biletów na metro były wysokie. Przy średnich zarobkach dla regionu Santiago ok. 3000 złotych, miesięczne, wydatki na przejazdy metrem wynosiły od 500 do 1000 złotych, co dla wielu mieszkańców było ceną zaporową. M. Mazzini, Protesty w Chile. Największe od upadku dyktatury Pinocheta, Polityka, https://www.polityka.pl/ tygodnikpolityka/swiat/1929856,1,protesty-w-chile-najwieksze-od-upadku-dyktatury-pinocheta (dostęp: 30.03.2021).

${ }^{38}$ Po poduyżkach z 6 października 2019 roku cena za bilet $w$ chilijskim metrze $w$ godzinach szczytu jest najwyższą u całej Ameryce Łacińskiej (830 peso). J. Bartlett, Chile students' mass fare-dodging expands into city-wide protest, „The Guardian”, https://www.theguardian.com/ world/2019/oct/18/chile-students-mass-fare-dodging-expands-into-city-wide-protest (dostęp: 30.03.2021). 
„brutalnych nierówności” ${ }^{39}$. Mimo że Chile to jedno z najlepiej rozwiniętych państu Ameryki Południowej z wysokim PKB na osobę (14 896 dolarów u 2019 roku ${ }^{40}$, to jest także w czołówce krajów o największych nierównościach społecznych ${ }^{41,42}$. Jednocześnie większość majątku pozostaje w rękach rodzin związanych z wcześniejszą władzą oraz klanów uczestniczących w negocjacjach transformacyjnych po 1989 roku³ . Ekonomiczny model gospodarki neoliberalnej sięga bouiem czasów generała Augusto Pinocheta, uspierając prywatyzowanie wielu dziedzin życia, na przykład opieki społecznej, edukacji, systemu emerytalnego ${ }^{44}$. Neoliberalny model przyczynił się do pogłębienia już istniejącego rozwarstwienia społecznego, narastających frustracji i przełożył się na nastroje obywateli. „Wielu socjologów porównuje Chile do tykającej bomby, która musiała w peunym momencie wybuchnąć. Gdy już się to stało, to ta eksplozja okazała się rzeczywiście guałtowna" ${ }^{45}$.

Po niespełna dwóch tygodniach od rozpoczęcia protestów sytuacja uległa eskalacji. Demonstranci zaczęli niszczyć miejską infrastrukturę w stolicy, w wielu częściach miasta dochodziło do starć między policją a protestującymi, plądrowano sklepy. Zniszczono 80 z 136 stacji metra ${ }^{46}$. W konsekwencji tych działań prezydent Sebastian Piñera wprowadził piętnastodniowy stan wyjątkowy w okręgu Santiago, wyprowadzając

39 T. Armus, „We are at war”: 8 dead in Chile's violent protests over social inequality, „The Washington Post”, https://www.washingtonpost.com/nation/2019/10/21/chile-protests-santiago-dead-state-emergency/ (dostęp: 30.03.2021).

40 Banco Mundial, PIB per cápita (US\$ a precios actuales) - Chile, https://datos.bancomundial. org/indicator/NY.GDP.PCAP.CD?locations=CL (dostęp: 6.04.2021).

${ }^{41}$ M. Piękoś, W Chile podział na lepszych i gorszych jest nie tylko ekonomiczny, ale też rasowy, „Krytyka Polityczna”, https://krytykapolityczna.pl/swiat/zamieszki-w-chile-michal-piekos/ (dostęp: 6.04.2021).

${ }^{42}$ Według Komisji ONZ ds. Ameryki Łacińskiej i Karaibów, w 2017 roku „1\% populacji w Chile kontrolowało 26,5\% łącznego majątku uszystkich obywateli, natomiast aż 50\% gospodarstu domouych o niższych dochodach posiadało dostęp do zaleduie 2,1\%”. P. González, La desigualdad que despertó a Chile, https://radio.uchile.cl/2019/10/28/la-desigualdad-que-desperto-a-chile/ (dostęp: 30.03.2021).

${ }_{43}$ M. Mazzini, Protesty $w$ Chile..., op. cit.

${ }^{44} \mathrm{Z}$ danych przedstawionych w raporcie OECD z 2017 roku wynika, że średnie opłaty za studia uynoszą 7156 dolarów. Dla porównania w USA opłata wynosi 8202 dolary. The Santiago Times, Chile's University Tuition Fees amongst world's highest, https://santiagotimes.cl/2017/09/15/ chiles-university-tuition-fees-amongst-worlds-highest/ (dostęp: 1.04.2021). Natomiast minimalna płaca w Chile wynosi 423 USD, z czego 50\% zatrudnionych pracouników zarabia 562 USD miesięcznie. P. Fernanda, Protestas en Chile: 4 claves para entender la furia y el estallido social en el país sudamericano, https:/wuw.bbc.com/mundo/noticias-america-latina-50115798 (dostęp: 1.04.2021). 30\% umów zawieranych jest na krótki okres i trwa średnio 10 miesięcy. K. Sehnbruch, How Pinochet's economic model led to the current crisis engulfing Chile, https://www.theguardian.com/world/2019/oct/30/pinochet-economic-model-current-crisis-chile (dostęp: 1.04.2021).

${ }^{45}$ K. Walczouska, Goraca sytuacja w Chile nie ustaje. Polka ttumaczy, czego chca obywatele, Onet, https://podroze.onet.pl/aktualnosci/protesty-w-chile-polka-tlumaczy-przyczyne-santiago-zycie-w-chile/z54mpu2 (dostęp: 25.03.2021).

${ }^{46}$ Bnamericas, Metro de Santiago: 80 estaciones danadas o destruidas durante protestas, https://wuw.bnamericas.com/es/noticias/metro-de-santiago-80-estaciones-danadas-o-destruidas-durante-protestas (dostęp: 6.04.2021). 
armię na ulice u celu egzekwowania porządku i zapobieganiu niszczenia mienia publicznego. Wprowadzono również godzinę policyjną, środek, który ostatni raz zastosowano w Santiago za czasów Pinocheta w 1987 roku $^{47}$. W kolejnych dniach stan wyjątkowy objął już 12 z 16 prowincji ${ }^{48}$. Aparat represji zareagował dość brutalnie. ONZ w raporcie opublikowanym w grudniu 2019 roku rekomendowało „natychmiastowe zaniechanie masouego użycia broni w celu kontroli demonstracji" ${ }^{49}$. Publikacja poustała w wyniku badań przeprowadzonych w siedmiu prowincjach Chile i miała na celu analizę sytuacji podczas protestów (październik-grudzień 2019) oraz ocenę działań władz $w$ kontekście przestrzegania praw człowieka. Na podstawie przeprowadzonych wywiadów, zarówno z ofiarami, jak i policjantami, przedstawicielami władz lokalnych/ państwowych, stwierdzono szereg naruszeń, których dopuszczały się służby, w tym tortury, zabójstua, znęcanie się, różne formy przemocy seksualnej ${ }^{50}$. Według ekspertów „policja nie rozróżniała ludzi demonstrujących pokojowo od tych agresyunych”, uskazując, że w wielu przypadkach użycie broni było nieproporcjonalne i nieuzasadnione, co $w$ konsekwencji przełożyło się na liczbę ofiar ${ }^{51}$. Oficjalne dane wskazują, że między 18 października a 6 grudnia zginęło 26 osób, aresztowano 28 000, prawie 5000 osób zostało rannych, w tym 2800 funkcjonariuszy ${ }^{52}$. W raporcie enigmatycznie określono, że „przyczyn protestów jest wiele, w tym nieróuności społeczne i ekonomiczne” ${ }^{53}$.

W wystąpieniu telewizyjnym Piñera powiedział:

Prowadzimy [w Chile - przyp. aut.] wojnę z potężnym i nieustępliuym urogiem, który nie szanuje niczego ani nikogo i jest gotów stosować przemoc bez żadnych ograniczeń, nawet jeśli oznacza to śmierć ludzi, a jedynym celem jest spowodowanie jak największej szkody ${ }^{54}$.

Retoryka ta spotkała się z ogólnym niezadowoleniem protestujących. Należy podkreślić, że Piñera wycofał się z poduyżek komunikacji miejskiej 19 października, podkreślając, „że z pokorą i uwagą wysłuchał prośby protestujących” ”5, co w żaden sposób nie przyczyniło się do zmiany nastrojów społecznych. Na tym etapie na ulicy zostały

${ }_{47}$ El Desconcierto, Decretan inédito toque de queda en Santiago tras fracaso del gobierno en contener ola de protestas, https://wuw.eldesconcierto.cl/2019/10/19/decretan-inedito-toque-de-queda-en-santiago-tras-fracaso-del-gobierno-en-contener-ola-de-protestas/ (dostęp: 25.03.2021). ${ }_{48}$ M. Mazzini, op. cit.

${ }^{49}$ United Nations, Raport of the Mission to Chile 30 October - 22 November 2019, s. 31, https://www.ohchr.org/Documents/Countries/CL/Report_Chile_2019_EN.pdf (dostęp: 6.04.2021).

${ }^{50}$ Ibidem, s. 29.

51 Ibidem.

${ }^{52}$ United Nations, UN human rights report cites 'multiple root causes' of deadly Chile protests, https://news.un.org/en/story/2019/12/1053491 (dostęp: 6.04.2021).

53 United Nations, Raport of the Mission to Chile..., op. cit., s. 29.

${ }^{54}$ BBC Neus Mundo, Protestas en Chile: confirman la muerte de 15 personas mientras continúan los disturbios pese a que el gobierno suspendió el alza de las tarifas del metro en Santiago, BBC, https://wuw.bbc.com/mundo/noticias-america-latina-50112080 (dostęp: 30.03.2021).

${ }_{55}$ P. Molina, Estado de emergencia en Chile: la jornada de protestas en Santiago que llevó al presidente Pinera a suspender el alza del precio del metro, BBC, https://wuw.bbc.com/ mundo/noticias-america-latina-50112071, (dostęp: 6.04.2021). 
wyrażone frustracje, które zbierały się w ludziach od wielu lat. Trudno jasno uskazać, co było celem protestujących, jedni chcieli zmiany władzy, inni zmiany konstytucji ${ }^{56}$. Według chilijskiego politologa Nicolasa Mirandy Olivaresa ,protesty nie przekształciły się jeszcze $w$ konwencjonalny ruch społeczny z jasnymi i spójnymi żądaniami, nie ma zatem przedstawicieli, którzy mogliby negocjować z rządem"57.

\section{Metoda badawcza - opis i weryfikacja}

Jak uspominano wcześniej, głóunym celem artykułu jest weryfikacja podejścia metodologicznego zaproponowanego przez Vogela i innych. Postulują oni, że „graffiti może stanowić formę społeczno-politycznego komentarza na poziomie lokalnym" 58 , będąc tym samym cennym źródłem wiedzy dla badaczy i decydentów na temat społeczeństw funkcjonujących w strefach/okresach konfliktu ${ }^{59}$. Treści społeczno-polityczno-kulturowe zawarte w sztuce ulicznej reprezentują w szczególności głos tych grup społecznych, które są marginalizowane lub wykluczone z głównego dyskursu lub nie mają dostępu do mediów mainstreamouych. Choć autorzy tej propozycji ograniczają swoje rozważania do przestrzeni konfliktu, w naszym przekonaniu zaproponowane podejście jest bardziej uniwersalne. Co więcej, zastosowanie tego procesu pozwala na rekonstrukcję narracji funkcjonujących w przestrzeniach miejskich niezależnie od stanu wiedzy badaczy na temat analizowanych społeczności. Posiadana wiedza będzie się przekładała bowiem nie na jakość, ale szczegółowość podejmowanych analiz. W przypadku braku wiedzy szczegółowej na temat danych społeczności analizy mogą stanowić punkt wyjścia do dalszych, bardziej szczegółowych badań.

Przydatność i efektywność tej metody u przypadku badania sztuki ulicznej w okresie braku konfliktu uzasadniamy następująco. Kluczową różnicą między okresem konfliktu i jego braku jest odmienna dynamika funkcjonowania sztuki ulicznej. W tym pieruszym przypadku jest ona zintensyfikowana, co oznacza nie tylko większą liczbę prac funkcjonujących w przestrzeni publicznej, lecz także wyraźną ich rotację, różnorodność tematyczną i ograniczenie przekazów głównie do aktualnych uydarzeń. W przypadku braku konfliktu liczba prac i ich rotacyjność jest zdecydowanie mniejsza. Przekłada się to na większą trwałość, a tym samym dłuższy czas ekspozycji, możliwość spokojnej i wielorazowej „konsumpcji” treści. Odmienna będzie róunież tematyka prac. Poza aktualnymi problemami znajdą się tam róunież uniwersalne treści. Niezmienna pozostaje jednak funkcja. W obu przypadkach różne przejauy sztuki ulicznej mogą wiele powiedzieć na temat samych treści i autorów, ale także o stosunku lokalnych

56 J. Franklin, Chile protesters: „We are subjugated by the rich. It's time for that to end”, „The Guardian”, https://www.theguardian.com/world/2019/oct/30/chile-protests-portraits-protesters-sebastian-pinera (dostęp: 6.04.2021).

${ }^{57}$ M. Nowak, Byli wzorem dla Polski, tona w narodowym chaosie. W Chile 17 zabitych $i$ tysiace aresztowanych, OKO Press, https://oko.press/byli-wzorem-dla-polski-tonaw-narodowym-chaosie-w-chile-17-zabitych-i-tysiace-aresztowanych/ (dostęp: 6.04.2021).

${ }^{58}$ B. Vogel i in., op. cit., s. 2148.

${ }^{59}$ Ibidem. 
społeczności i uładz do ich obecności u przestrzeni publicznej. Miejsce ekspozycji, zajmowana powierzchnia, interakcja z pracami (lub jej brak), dialogiczność - to kluczowe pozawizualne składniki pozwalające na pozyskanie wiedzy na temat określonych grup społecznych.

Proponowana metoda badawcza obejmuje dwie powiązane ze sobą perspektywy. Pierusza optyka koncentruje się na uchuyceniu i analizowaniu relacji między miejscem, czasem poustawania prac i ich autorami (gdzie, kiedy i kto). Druga skupia się na treści i identyfikacji funkcji komunikacujnych (co). Dzieli się ona na subkategorie ukierunkouujące dalsze analizy - nakreślanie linii podziału, identyfikowanie treści kluczourych dla danych grup, społeczno-politycznej reprezentacji, rekonstrukcję alternatywnych narracji odnośnie do dominujących mitów, historii, postaci i uydarzeń, sposoby upamiętniania ważnych postaci. Jak podkreślają autorzy (Vogel i in.), oba aspekty tworzą proces analityczny pozwalający akademikom na pozyskanie wiedzy na temat postulatów, problemów, żądań, dążeń funkcjonujących u danych społeczeństwach. Należy mieć na uwadze, że wyszczególnione obszary niejednokrotnie nakładają się na siebie i ciężko nakreślić sztywne granice między nimi, jednakże proces ten pozwala na „zrozumienie graffiti i jego politycznego przekazu oraz znaczenia w usystematyzowany sposób”60.

Dla klarowności uywodu połączono opis poszczególnych elementów składowych metody badawczej z analizą mającą na celu jej weryfikację. Materiał badauczy składał się z 195 fotografii zrobionych przez nas w dniach 1-12 grudnia 2019 roku w stolicy Chile Santiago. W analizach uwzględniliśmy prace zlokalizowane między placem La Moneda, przy którym znajdują się budynki kluczowych instytucji państwowych i główny budynek Uniwersytetu Chilijskiego a Placem Baquedano. Na odcinku tym odbywała się większość protestów. Brak kompleksowej wiedzy na temat chilijskiej historii, sytuacji społeczno-politycznej, kulturowej przekłada się na przyjęcie konkretnej optyki, przygodnych obserwatorów bieżącego życia miasta, koncentrując się na rekonstrukcji historii konfliktu społecznego z perspektywy protestujących.

\section{Gdzie, kiedy, kło - czyli aspekty pozawizualne}

\section{Gdzie - czyli perspekływa przestrzenna}

Przestrzeń, kontekst czasu, autorstua i tematyka stanowią kluczowe składniki czytania i interpretacji sztuki ulicznej, przy czym lokalizacja jest zasadniczym aspektem z uwagi na pełnione funkcje: widoczność, zasięg promowanych treści, możliwości interakcji z pracami oraz przede wszystkim kontekst. Interakcja zachodzi bowiem nie tylko na linii nadauca-odbiorca, lecz także między pracą a miejscem, które „nie jest po prostu statyczną, fizyczną lokalizacją; jest momentem w procesie społecznym, w wyniku

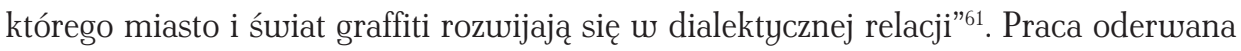
od swojej lokalizacji, mimo że zachouuje styl, kolory, symbole, traci część suojego

${ }_{60}$ B. Vogel i in., op. cit., s. 2050.

${ }^{61}$ J. Ferrell, R.D. Weide, Spot theory, „City” 2010, t. 14, nr 1-2, s. 50. 
znaczenia $^{62}$. Usytuowanie prac jest niejednokrotnie kluczem do zrozumienia pełnego przekazu pracy ${ }^{63}$. Wkroczenie z określonymi komunikatami do głównych, ważnych i popularnych fragmentów przestrzeni miejskiej pozwala na dotarcie do szerokiego grona odbiorców, zwiększając potencjalnie zasięg ich oddziaływania. Jednak nie tylko kryterium popularności czy ogólnodostępności danej lokalizacji jest tutaj kluczowe, lecz także ulokowanie prac w obrębie określonych składników owej przestrzeni. Graffiti ulokowane na reprezentacyjnych budynkach, pomnikach będzie generować róunież różne stopnie interakcji. Z perspektyuy twórców i protagonistów jest to równoznaczne z symbolicznym „przejęciem” danej przestrzeni i włączeniem jej do dyskursu. Antagoniści z kolei będą zarzucać niszczenie, profanację ouych miejsc, wpisując się w długą tradycję traktowania sztuki ulicznej jako wandalizmu ${ }^{64}$. Nie pozostaną jednak obojętni na sam przekaz. Odpowiedzią będzie więc usuwanie prac lub zastępowanie ich własnymi treściami. Street art, a w szczególności graffiti jest niejednokrotnie wykorzystywane róunież do znakowania przestrzeni przez poszczególne grupy, wskazując przy tym nie tylko dominację danych grup w określonej przestrzeni, lecz także kluczowe dla nich idee i wartości ${ }^{65}$.

Sztuka uliczna celowo i świadomie pozycjonuje się zatem w odniesieniu do określonych aspektów środowiska miejskiego ${ }^{66}$. W przypadku egipskiej odsłony Arabskiej Wiosny lokalizacja przekazu skierowanego zarówno do mieszkańców, jak i rządzących była celowa. „Głównymi przestrzeniami tej dyskusji wizualnych były konkretne miejsca, jak ulica Mahmouda w Kairze, gdzie znajdowało się Ministerstwo Spraw Wewnętrznych, centrum sterowania terrorem policyjnego reżimu"67.

Analizowany materiał ogranicza się do określonej przestrzeni miejskiej w Santiago de Chile ${ }^{68}$. Różnorodne formy street artu dominowały niemalże na pełnej długości objętego analizą obszaru, stanowiąc swoistą kronikę protestów. Prowadzona obserwacja potwierdziła dużą dynamikę zuiązaną z liczbą i rotacyjnością prac. Były one modyfikowane, rozbudowywane przez innych twórców, zamalowywane przez służby

${ }^{62}$ Ibidem.

${ }^{63}$ B. Vogel i in., op. cit., s. 2155.

${ }^{64}$ Doskonałą egzemplifikacją były protesty w odpowiedzi na wyrok Trybunału Konstytucyjnego u sprawie aborcji, które przetoczyły się przez Polskę. W ich trakcie na wielu budynkach, pomnikach i kościołach pojawiło się graffiti, które było traktowane w kategoriach wandalizmu. W szczególności dotyczy to kościołóu. Naruszone zostało bowiem sacrum, złamane tabu. W Polsce budynki należące do Kościoła katolickiego są nietykalne. Reakcje społeczne nie były jednak tak ostre w przypadku malowania graffiti na meczetach. Przykłady te pokazują rolę relacji zachodzącej między lokalizacją street artu a kulturową symboliką i wartościami.

${ }^{65} \mathrm{Na}$ początku lat dziewięćdziesiatych XX wieku było to doskonale widoczne na polskich osiedlach. Krzyże celtyckie, symbole anarchii i inne subkulturowe treści wyznaczały tereny będące pod kontrolą określonych subkultur młodzieżowych. Aktualnie taką rolę pełni graffiti tworzone przez kibiców piłkarskich, co jest widoczne w szczególności w miastach, w których funkcjonuje więcej niż jeden klub.

${ }^{66}$ S. Hansen, F. Danny, «This is not a Banksy!»: street art as aesthetic protest, „Continuum” 2015, t. 29(6), s. 899.

${ }^{67}$ N. Mirzoeff, op. cit., s. 272.

${ }^{68}$ Tego typu obserwacje poutarzały się róunież w innych częściach miasta. 
miejskie lub też usuwane przez samych mieszkańców Santiago niezgadzających się z protestującymi. Dynamika zmian powiązana była róunież z „harmonogramem” protestów. W dniu protestów pojawiały się całe grupy naklejające/malujące nowe prace, zastępując te już istniejące. Tematyka była zróżnicowana i zostanie omówiona w dalszej części artykułu.

Osobno spojrzeć należy na trzy budynki i ich lokalizacje. Pieruszym jest główny gmach Uniwersytetu Chilijskiego, który stoi niemalże naprzeciwko pałacu prezydenckiego La Moneda, jak również w najbliższym sąsiedztwie głównych chilijskich ministerstw. Tuż obok znajduje się ogromna flaga narodowa. Wszystkie te obiekty stanowią, zgodnie z koncepcją banalnego nacjonalizmu Michaela Billiga ${ }^{70}$, „narodowe przypominacze", kluczowe dla nacjonalistycznych narracji. Po jednej stronie mamy więc atrybuty władzy państwowej, po drugiej - przejaw oddolnych działań. Studenci aktyunie bowiem angażowali się w protesty, a sam budynek uniwersytetu był nie tylko punktem spotkań i dyskusji, lecz także miejscem schronienia i pomocy dla uczestników protestów w trakcie starć z policją. Jednocześnie front budynku stał się jedną z istotnych przestrzeni komunikacyjnych. Wielkie transparenty zasłaniały niemalże całą fasadę budynku. W dolnej jego części zostały ulokowane mniejsze plakaty, ilustracje i graffiti. Wszystkie prace uyrażały postulaty studentów, prezentowały ofiary policyjnej przemocy, wzywały do czynnego udziału w protestach. Z perspektywy przestrzeni i komunikacji budynek uniwersytecki i widniejące na nim treści były ogólnodostępne i stanowiły kontrapunkt dla oficjalnych narracji. Trudno minąć tę część miasta bez dostrzeżenia studenckiego przekazu. Całość pełnić miała więc funkcję przypominania się władzy, upominania się o suoje prawa, była żądaniem zmian.

Kolejną ważną przestrzenią jest Centrum Gabrieli Mistral, które na co dzień jest ośrodkiem kulturalnym, otwartym dla szerokiej publiczności i promującym różnorodne formy sztuki. Kojarzone z przestrzenią zapraszającą do dyskusji na problemy społeczne Centrum zostało „przejęte” przez protestujących za cichym przyzwoleniem jego władz. Zewnętrzna fasada, podobnie jak u przypadku budynku uniwersytetu, pełni funkcję otwartej galerii. O ile jednak w przypadku chilijskiej uczelni dominowały wielkopowierzchniowe transparenty, o tyle ściany centrum pokrywały zróżnicowane przejauy street artu autorstua różnorodnych środowisk. Ta otwarta galeria miała bardzo dynamiczny charakter. Umieszczane prace zmieniały się niemalże każdego dnia, pokazując tym samym bogactuo wizualne. Nie tylko fasada budynku została "przejęta” przez protestujących. Centrum organizowało dyskusje odnośnie do aktualnej sytuacji w Chile, a w trakcie protestów było przekształcane na szpital polowy, w którym udzielano pieruszej pomocy.

${ }^{69}$ Mowa tutaj o większych, zorganizowanych demonstracjach, mniejsze wydarzenia i/lub starcia z policją zachodziły bowiem codziennie $\mathrm{w}$ analizowanym okresie.

70 Zob. M. Billig, Banalny nacjonalizm, przeł. M. Sekerdej, Wydawnictuo Znak, Kraków 2008. 


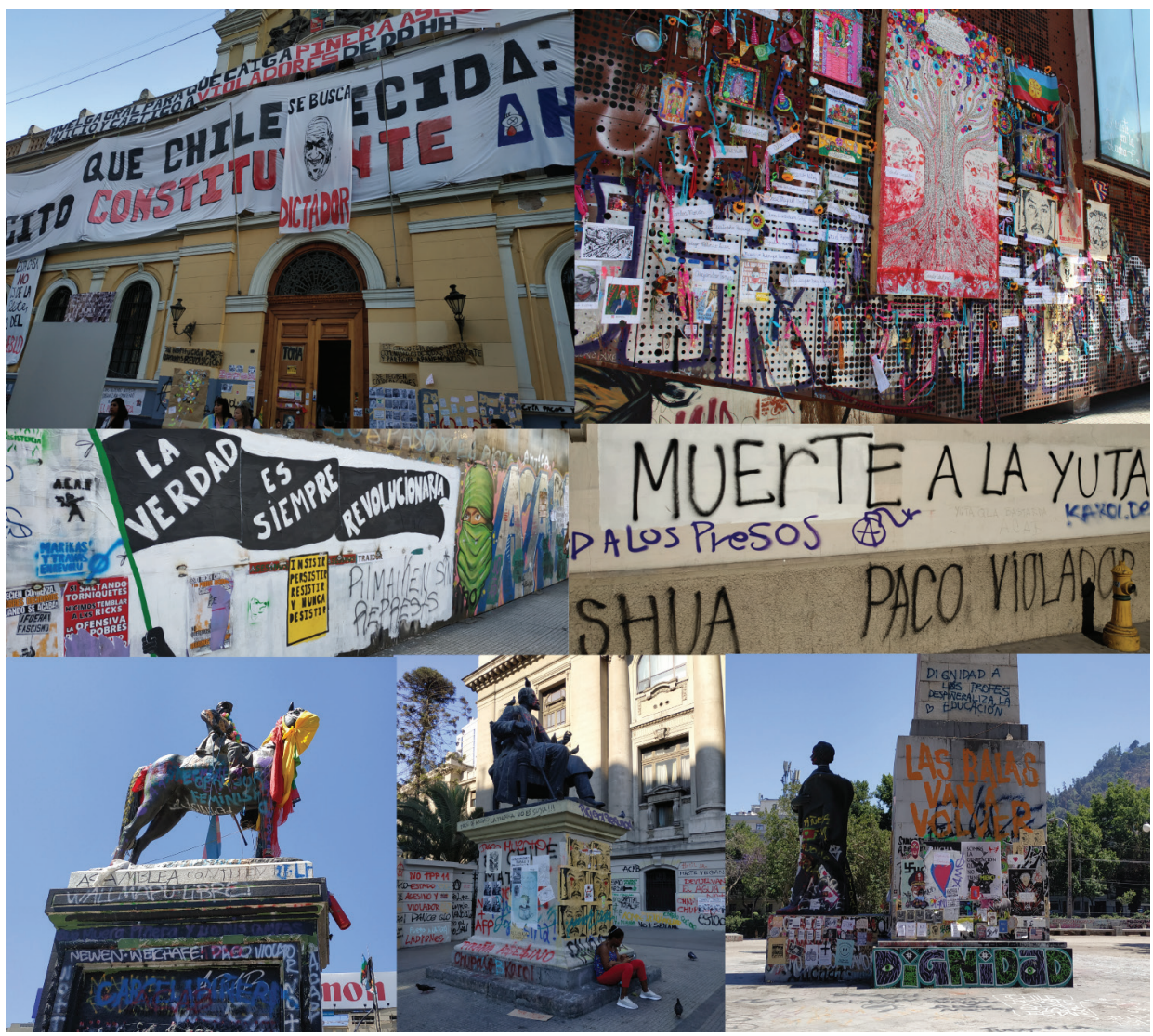

Ilustracja 1. Przykłady street artu zlokalizowanych na różnych składnikach sztuki ulicznej. Od górnego lewego górnego rogu: budynek Uniwersytetu Chilijskiego, Centrum Gabrieli Mistral, ściany ulicznych budynków, pomniki

Źródło: fotografie własne.

Kluczouym składnikiem przestrzeni miejskiej „przejętej” przez protestujących były pomniki. Nie tylko cokoły pomników stawały się przestrzenią zapełnianą przez graffiti, plakaty i inne przejawy street artu, lecz także same postacie stawały się częścią narracji. Większość z nich miała zamalowane czerwoną farbą jedno oko, co w kontekście protestów było symbolem sprzeciuu wobec policyjnej przemocy ${ }^{71}$. W szerszym kontekście interpretacyjnym traktować to można jako podkreślenie uspólnoty. Nie chodziło zuykle bowiem o obalenie pomników, zanegowanie postaci na nich przedstawianych, ale symboliczne podkreślenie, że ci wielcy ludzie są częścią nas, każdy może być ofiarą systemu represji policji. Pomniki zyskiwały również nowe elementy - flagę chilijską lub mapuchańską, czerwoną lub zieloną bandanę, będące kolejno symbolem studenckiej rewolty z 2010 roku i ruchu feministycznego.

\footnotetext{
${ }^{71}$ Szerzej o tym symbolu piszemy u dalszej części tekstu.
} 
Wyjątkiem był pomnik, który stał się fundamentalnym składnikiem i symbolem chilijskich protestów, uraz z placem, na którym się znajdował. Mowa tutaj o figurze Manuela Baquedano. Monument ten był jednym z charakterystycznych obiektów Santiago, zlokalizowanym na placu nazwanym róunież nazwiskiem generała. Dla części Chilijczyków generał był bohaterem narodowym z czasów konfliktu z północnymi sąsiadami Peru i Boliwią. Dla innych z kolei postać ta jawi się jako symbol eksterminacji rdzennych mieszkańców, w trakcie podporządkowywania i włączania do chilijskiego państwa Auracanii, południowego regionu zamieszkiwanego przez Mapuche. Pomnik ten symbolizuje również linię podziału przestrzeni miejskiej na biedniejsze downtown i bogate uptown. Reprezentuje ponadto spór między starym (utrzymywanym przez władze) a nowym (reprezentowanym przez postulaty protestujących) porządkiem. Przejęcie kontroli nad pomnikiem, jak również całym placem stało się celem zarówno protestujących, jak i policji. Monument był więc świadkiem największych zgromadzeń od momentu wybuchu protestów pod koniec 2019 roku, w tym jednego z największych w Chile. 25 października, kiedy ma ulice wyszło ponad milion Chilijczyków, sam pomnik również stał się częścią symbolicznej wojny. Dziesiątki razy był malowany na różne kolory, w tym najczęściej na czerwono, jako symbol przemocy policyjnej. Wieszane były na nim dziesiątki transparentów oraz flag i innych symboli protestów. Plac został przechrzczony przez protestujących na Plac Godności (Plaza Dignidad), stając się nie tylko jednym z głównych miejsc protestów, lecz także najbardziej dramatycznych starć z policją ${ }^{72}$. O istotności przejmowania i odzyskiwania przestrzeni miejskiej świadczą działania władz Santiago oraz grup i organizacji stojących w kontrze do protestujących. Zarówno sam pomnik Baquedano, jak i fasady budynków, w tym także Centrum Gabrieli Mistral były zamalowywane jednolitym kolorem przez uładzę, aby kolejnego dnia znów zapełniać się nouymi pracami demonstrantów.

\section{Kiedy - czyli temporalność szłuki ulicznej}

Główną specyfiką street artu, a graffiti u szczególności, jest jego temporalność. Reprezentuje ono wydarzenia pochodzące z określonego czasu, a pozytywny lub negatywny stosunek do utworów może ulegać zmianie ${ }^{73}$. Pomijając komercyjne murale, u większości przypadków żywotność sztuki ulicznej w przestrzeni miejskiej jest krótka. Prace są modyfikowane poprzez dokładanie kolejnych warstu wizualnych, zmieniających ich semantykę. Są one zamalowywane przez służby miejskie lub innych artystów chcących „przejąć” daną przestrzeń. W końcu zanikają w wyniku naturalnych procesów degradacyjnych ${ }^{74}$. Życie miasta jest podporządkowane odbywającym się w nim wydarzeniom, które niejednokrotnie przynoszą nowe przejauy street artu. Sztuka miejska funkcjonuje w okresach zarówno konfliktu, jak i pokoju. W zależności od

\footnotetext{
${ }^{72}$ Po duukrotnej próbie spalenia pomnika na początku marca 2021 roku władze zdecydowały się zdemontować pomnik i poddać go renowacji. Sam plac jest pod ciągłą kontrolą policji, która próbuje nie dopuścić do zgromadzeń.

${ }_{73}$ B. Vogel i in., op. cit., s. 2157.

${ }^{74}$ Zob. S. Hansen, F. Danny, op. cit., s. 898.
} 
czasu będzie zmieniać się dynamika jej pojawiania się. Okresy gorące charakteryzować się będą nie tylko większą intensyunością graffiti, lecz także bardziej aktualnymi i często modyfikowanymi treściami. Pozwala to na identyfikacje głównej osi sporu/konfliktów, punktów zapalnych, żądań, głównych aktorów, linii podziałów. Nie oznacza to, że w okresach spokojnych sztuka uliczna nie dostarcza cennej wiedzy. W odróżnieniu do okresów gorących z całą peunością dynamika zmian będzie znacznie mniejsza. Mniejsza będzie róunież liczba prac. Z poznauczej perspektyuy analizouanie sztuki ulicznej w sytuacji braku konfliktu pozwoli na identyfikację katalogu różnorodnych problemów podnoszonych przez określone środowiska. Potencjalnie większa może być reprezentacja podmiotów stojących za określonymi przejawami street artu, w sytuacji konfliktu dominować będą bowiem głównie aktorzy bezpośrednio zaangażowani. Poznanie nie tylko katalogu potencjalnych problemów, wartości, idei będzie kluczowe $\mathrm{w}$ trakcie analizy prac w okresie braku konfliktu. Interesujące powinny być również warstuy semiotyczna i semantyczna funkcjonujące $w$ analizowanych przekazach, jak również warstwa językowa. Dzięki temu możliwe jest uchwycenie typouych dla danych środowisk kodów semiotycznych i semantycznych, co w konsekwencji pozwala na sprawdzenie, czy i w jakim stopniu funkcjonują one w szerszym dyskursie i różnych sytuacjach dyskursywnych ${ }^{75}$. Podział na okres konfliktu i braku konfliktu dostarcza jeszcze jedną istotną dystynkcję - treści inkluzywne i wykluczające. Zuykkle dotyczy to prac poustających odgórnie. W pieruszym przypadku są to prace poustające na zlecenie władz i służące interesom władzy. Przykładem mogą być nacjonalistyczne murale meksykańskie, pełniące funkcję uytwarzania uspólnoty narodowej lub politycznej, jak w przypadku działań Salvadora Allende w Chile ${ }^{76}$. W drugim przypadku mamy do czynienia z przypadkami stygmatyzacji określonych grup społecznych z wykorzystaniem sztuki ulicznej. Działania takie prowadziło na podporządkowanych terenach Państwo Islamskie w odniesieniu do stawiających opór grup, głóunie chrześcijan i jazydów ${ }^{77}$.

W przypadku analizowanego materiału uszystkie prace poustały w okresie gorącym. Potwierdzone zostały wszystkie cechy typowe dla społeczeństw funkcjonujących w okresie konfliktu.

\footnotetext{
75 Śledząc polski dyskurs odnoszący się do środowisk LGBT+, można zauważyć, że określone negatywne pojęcia, symbole, metafory funkcjonujące u publicznym dyskursie pojawiały się wcześniej w postaci graffiti, plakatów i wlepek rozmieszczanych w przestrzeni miejskiej przez środowiska skrajnej prawicy. Z perspektywy badaczy analiza takich przekazów pozwala na identyfikację źródłowych tekstów i aktorów stojących za takimi treściami. W perspektywie komunikacyjnej jawi się to jako możliwość piętnowania określonych przekazów, stygmatyzacja grup społecznych zamieszczających takie treści czy też u końcu przygotowywanie kontrnarracji. ${ }_{76}$ Zob. S.A. Lewisohn, Mexican Murals and Diego Rivera, „Parnassus" 1935, t. 7, nr 7, s. 11-12; M. Leszek, Mural jako forma plastyczna w przestrzeni architektonicznej i urbanistycznej Meksyku, „Architectus” 2019, nr 3(59), s. 41-56; B. Rolston, op. cit., s. 113-137.

${ }^{77}$ B. Vogel i in., op. cit., s. 2157.
} 


\section{Kło - czyli identyfikacja głównych akłorów}

Kolejną perspektywą pozwalającą na rekonstrukcję znaczeń sztuki ulicznej jest identyfikacja twórców. Prace powstające u sposób nielegalny zuykle charakteryzują się anonimowością, choć poprzez określone elementy semiotyczne czy określony styl możliwa jest identyfikacja autora. W kontekście badauczym identyfikacja jednostek zuykle nie jest kluczowa. Ważniejsze jest uchwycenie szerszych grup stojących za określonymi pracami, aby móc zidentyfikować ichniejsze wartości czy idee.

W okresie protestów, kiedy dynamika sztuki ulicznej jest dość duża, ciężko jest jednoznacznie uchwycić dominujących twórców. W przypadku analizowanego materiału można jednak mówić o dwóch typach aktorów. Z jednej strony będą to twórcy pragnący działać anonimowo. Nie zostawiając żadnych uskazówek odnośnie do określonej przynależności ideologicznej czy też instytucjonalnej, propagują postulaty typowe dla całej grupy protestu. Do grupy tej zaliczać się będą również prace odnoszące się do określonych idei, bez uskazywania na konkretne środowiska. Przykłady wchodzące w zakres analiz pokazują dominację uszelkiego rodzaju środowisk lewicowych i skrajnie lewicouych, co uskazuje, że nie wszystkie opcje polityczne są reprezentowane w trwających protestach ${ }^{78}$. Widoczne były środowiska feministyczne, które skoncentrowały się na komunikowaniu istotnych dla nich postulatów i problemów, bez uskazywania politycznych afiliacji. W identyczny sposób funkcjonowały treści odnoszące się do rdzennych mieszkańców Chile.

Drugim typem aktorów są autorzy/kolektywy oraz organizacje, które umieszczają w swoich pracach elementy identyfikacyjne - nazwy organizacji lub ugrupowania politycznego. W sporej części przypadków na plakatach pojawiały się elementy identyfikacyjne $\mathrm{w}$ postaci nazw kont na Instagramie. Za owymi kontami stały zarówno pojedyncze osoby, które w ten sposób promowały również swoje inne projekty, jak i konta „zbiorowe”, pełniące funkcję wirtualnych galerii. Pokazuje to, że sztuka uliczna ma ogromny potencjał transmedialny. W prosty sposób da się ją przenieść i zaadoptować na potrzeby różnych mediów i kanałów komunikacji. Na tej podstawie możliwe jest tworzenie opowieści transmedialnych, rozumianych tutaj za Henrym Jenkinsem jako „wielowątkowa i zróżnicowana historia, która odsłaniana jest na różnych platformach medialnych, przy czym każde medium ma swój oddzielny wkład $\mathrm{w}$ tworzenie i rozwijanie fikcyjnego świata ${ }^{79}$ ". Publikowane $w$ przestrzeni wirtualnej prace nie tylko są tuórczo rozwijane, lecz także, w oderwaniu od miejsca, w którym zostały pierwotnie opublikowane, odpowiednio skompilowane przekładają się na generowanie licznych narracji i interpretacji wydarzeń.

\footnotetext{
${ }^{78}$ Wraz z rozwojem protestu również środowiska skrajnej prawicy pojawiły się na ulicach Santiago. Ich działania skoncentrowały się jednak na manifestowaniu poglądóu w trakcie demonstracji, atakach na lewicowych protestujących i usuwaniu graffiti. Nie znaleziono jednak żadnego przykładu prawicowej sztuki ulicznej.

${ }^{79}$ H. Jenkins, op. cit., s. 260.
} 


\section{Co - czyli treści sztuki ulicznej}

Ostatni ze składników analizy odnosi się do treści - głównej funkcji sztuki ulicznej. Analiza zawartości prac pozwala bowiem na identyfikację najważniejszych tematów komunikowanych przez twórców, a tym samym promowanych przez nich idei, wartości i postulatów. Nakreślenia linii podziałów, uskazania głównych punktów oporu, identyfikacji środowisk reprezentowanych oraz kluczowych postaci i/lub wydarzeń pełniących rolę pamięci historycznej. Kiedy traktujemy sztukę uliczną jako symboliczną formę reprezentacji, możliwe jest „pozyskanie głębszej wiedzy o projektowanych tożsamościach i ideałach, ich symbolicznym znaczeniu oraz upływie, jaki artysta chce mieć

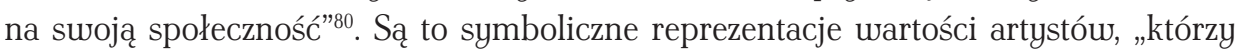
chcą rzucić wyzwanie kulturowej hegemonii lub dominującej kulturze" ${ }^{" 11}$. Rekonstrukcja obrazu świata na bazie sztuki ulicznej powinna obejmować zarówno analizy komunikatu i przekazu danego przejauru sztuki ulicznej (semantykę obrazu), lecz także warstuę semiotyczną. W artykule ograniczymy się do pierwszej kwestii, z uwagi na fakt, że warstuę semiotyczną analizowanych obrazów szeroko podjęliśmy w innej publikacjii².

\section{Linie podziału i wyrażanie sprzeciwu}

Jak uspomniano w części ustępnej, samo tworzenie sztuki ulicznej jest aktem oporu wymierzonym we władze, dominujący system polityczny, gospodarczy czy kulturoury. Treści street artu mają na celu przedstawienie kluczowych narracji dla określonych, zuykle wykluczonych społecznie lub medialnie społeczności, traktujących przestrzeń miejską jako kanał komunikacji, pozwalający przedstawić ich punkt widzenia oraz uprowadzić alternatywną względem głównego nurtu narrację. W kontekście kategorii „wyrażanie sprzeciuu” analiza prac powinna dążyć do identyfikacji kluczowych postaci, instytucji, problemów, zjawisk, które stanowią zarzewie konfliktu, zarysourują granicę podziałów, uskazują głównych aktorów, w których jest wymierzone ostrze krytyki/oporu.

W przypadku analizowanych w tym artykule obrazów z Santiago można wskazać kilka obszarów zapalnych, które funkcjonują na poziomie ogólnym i szczegółowym. W pieruszym przypadku ostrze krytyki jest wymierzone w całą klasę polityczną. Choć dominującą postacią jest urzędujący prezydent Sebastián Piñera, to u szerszym kontekście stanowi on jedynie symbol władzy. Atakowany jest także neoliberalny model gospodarki wprowadzony przez Augusto Pinocheta, który po przejęciu władzy w wyniku zamachu stanu w 1974 roku udrażał reformy proponowane przez amerykańską szkołę chicagouską. Chociaż z perspektywy międzynarodowej Chile stało się

\footnotetext{
${ }^{80}$ B. Vogel i in., op. cit., s. 2161.

${ }^{81}$ J. Clarke i in., Subcultures, Cultures, and Class [w:] Resistance through Rituals, red. S. Hall, T. Jefferson, Routledge, London 1976, s. 40.

${ }^{82}$ Zob. K. Lachouska, M. Pielużek, Miasto jako przestrzeń ideologiczna - analiza sztuki ulicznej towarzyszacej aktualnym protestom w Chile, „Annales Universitatis Paedagogicae Cracoviensis. Studia de Cultura” 2020, nr 12(2), s. 93-121.
} 
gospodarczym liderem regionu, to jednak weunątrz kraju nastąpiło pogłębienie różnic między bogatymi i biednymi. Piñera jest $w$ tym kontekście symbolem kontynuacji polityki prowadzonej przez chilijskiego dyktatora, co przejawia się pracami i hasłami zrównującymi obie postacie. Prezydent jest portretowany więc jako symbol drapieżnego kapitalizmu. Wyraźnie podkreślane są negatywne aspekty kapitalizmu (brak dostępu do darmowej edukacji, wysokie koszty życia, wykluczenie społeczne), ale także kapitalizm jako składnik uzależniający rządzących od zewnętrznych aktorów, zarówno korporacji, jak i innych państw. W tym ostatnim aspekcie, komunikując to symbolicznie w postaci marionetek reprezentujących najważniejsze osoby w państwie.

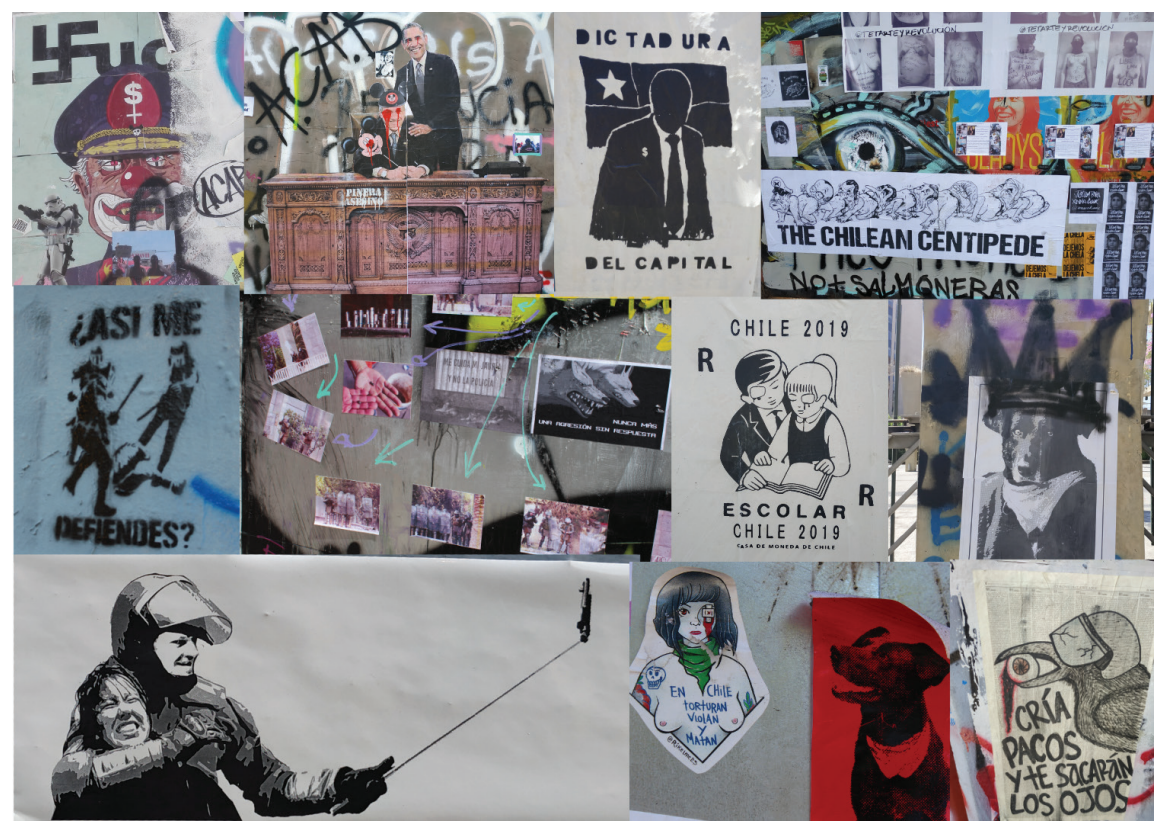

Ilustracja 2. Przykłady prac uskazujących głównych aktorów i problemy stanowiące główne źródło konfliktu

Źródło: fotografie własne.

Sprzeciu jest wyrażany róunież wobec braku rozliczeń z przeszłością. Jedną z najuymouniejszych prac $\mathrm{w}$ tym kontekście była „Chilijska stonoga”. Pokazuje ona ciąg kluczowych dla chilijskiej polityki osób. Pieruszą postacią jest Pinochet, a następnie pojawiają się kolejni prezydenci kraju, obrazowani u seksualnej pozycji podkreślającej podporządkowanie. W szerszym kontekście praca symbolizuje polityczną kontynuację, utrzymywanie neoliberalnego ładu, pogłębianie nieróuności, lecz także brak rozliczenia sprawców politycznych represji i tortur w czasie dyktatury Pinocheta, niewyjaśnienie spraw „zaginionych”³, dalszą marginalizację i uykluczanie rdzennej ludności. Wszystkie te kwestie uybrzmiewają na obrazach i tekstach widniejących na murach. Pinochet

${ }_{83}$ Terminem tym określa się osoby zatrzymane lub uprowadzone przez reżim Pinocheta, których los do dnia dzisiejszego pozostaje nieznany. 
i Piñera - ich nazwiska i wizerunki są też kluczową osią narracji na poziomie jednostek. Nie tylko zrównywani są jako autorytarni przedstawiciele władz, lecz także to na nich spada odpowiedzialność za ofiary protestów i antyrządowych wystąpień. W aktualnym kontekście Piñera jest obrazowany jako kontynuator brutalnych działań sił państwouych, przyzualający na policyjną przemoc, stale poszerzający zakres uprawnień aparatu represji. Obrazowane jest to w postaci listy lub galerii zdjęć ofiar aktualnych protestów uraz z nazwiskiem urzędującego prezydenta jako głóunego winnego takiego stanu rzeczy.

Przedstawiciele aparatu represji to kolejny istotny aktor street artowych narracji. Ta oś narracyjna była dominująca wśród analizowanych prac. Można ją podzielić na dwie grupy. Pierwsza, mniej liczna, to ogólny wyraz sprzeciuu względem przemocy ze strony państua. Wyraża się ona nawiązaniami do zabójstu i aktów przemocy względem protestującej rdzennej ludności, czego głóunym symbolem jest postać Camilo Catrillanci ${ }^{84}$ oraz psa Negro Matapacosa („czarnego zabójcę glin”) ${ }^{85}$, z charakterystyczną czeruoną bandaną, symbolizującą policyjną przemoc w trakcie studenckich protestów w Chile u 2010 roku. Drugą, dominującą częścią tej narracji, podkreślającą opór i sprzeciu wobec policji były prace pokazujące aktualne działania wymierzone w protestujących. Stanowią one nie tylko suoistą dokumentację działań aparatu represji, lecz także obrazują katalog przestępstu dokonywanych przez policję. Obrazowane jest to w postaci zdjęć prezentujących resztki nabojów znalezionych w miejscach protestu, ciężko uzbrojonych policjantów strzelających z bliskiej odległości z ostrej broni lub pociskami gazowymi uprost w protestujących, demonstrantów potrącanych lub rozjeżdżanych przez samochody Carabinieros. Policyjna przemoc i przestępstua są róunież pokazywane u symbolicznej formie. Krwawiące oko stało się jednym z kluczowych symboli aktualnych protestów ${ }^{86}$. Pojawia się ono w różnych formach nie tylko na większości prac, lecz także, jak uspominano wcześniej, miejskie pomniki stają się częścią owej narracji. Ważną kuestią jest również podkreślanie guałtów dokonywanych przez policję na zatrzymanych uczestniczkach protestów. Wszystkie te wizualne reprezentacje mają służyć podkreślaniu skali policyjnej przemocy. Jednocześnie stanowią one kontrnarrację wobec oficjalnych komunikatów władz dotyczących działań policji, wskazującą na protestujących jako agresorów; są historią opowiedzianą przez samych protestujących, co nie oznacza historii obiektywnej, pozbawionej manipulacji ${ }^{87}$.

${ }^{84}$ Do tej postaci wrócimy u dalszej części artykułu.

${ }^{85}$ Czarny pies z przewieszoną przez protestujących czerwoną bandaną towarzyszył protestującym studentom u trakcie demonstracji u 2010 roku. Atakował on policjantów w trakcie zamieszek, pozostając łagodnym względem samych protestujących.

${ }^{86}$ Oko stało się symbolem policyjnej przemocy. W trakcie tłumienia protestóu policja wielokrotnie strzelała protestującym w oczy. Tylko do końca listopada 2019 roku ponad 360 osób zostało zranionych w oczy, a w wielu przypadkach nastąpiła całkowita utrata wzroku - zob. United Nations. UN human rights report cites 'multiple root causes' of deadly Chile protests, 2019, https://neus.un.org/en/story/2019/12/1053491 (dostęp: 8.04.2021).

${ }^{87}$ Przykładem takiej manipulacji jest postać polskiego nauczyciela Mateusza Maja. Jego uizerunek lokowany jest przez protestujących wśród innych ofiar policyjnej przemocy. W rzeczywistości Polak zginął w wyniku nieszczęśliwego wypadku. Został on przypadkowo śmiertelnie postrzelony przez teścia, który próbował poustrzymać osoby, w trakcie protestu plądrujące jego sklep. 


\section{Upamiętnienie}

Analiza street artu z perspektywy portretowanych postaci, wydarzeń czy konfliktów pozwala na rekonstrukcję tropów historycznych stanowiących punkt odniesienia, ujaunienie kluczowych dla danych społeczności składników tożsamości i aspiracji, bohaterów, mitów czy wierzeń, a tym samym dostarcza szerszego kontekstu historycznego, kulturowego i politycznego. Każda społeczność ma swoich bohaterów, męczenników, „uybrańców”, mity i traumy, które często poprzez uwiecznianie na publicznych murach kształtują „krajobraz przestrzeni pamięci”. Mogą one stanowić usparcie lub alternatywę dla oficjalnej polityki historycznej konstruowanej przez władze ${ }^{88}$.

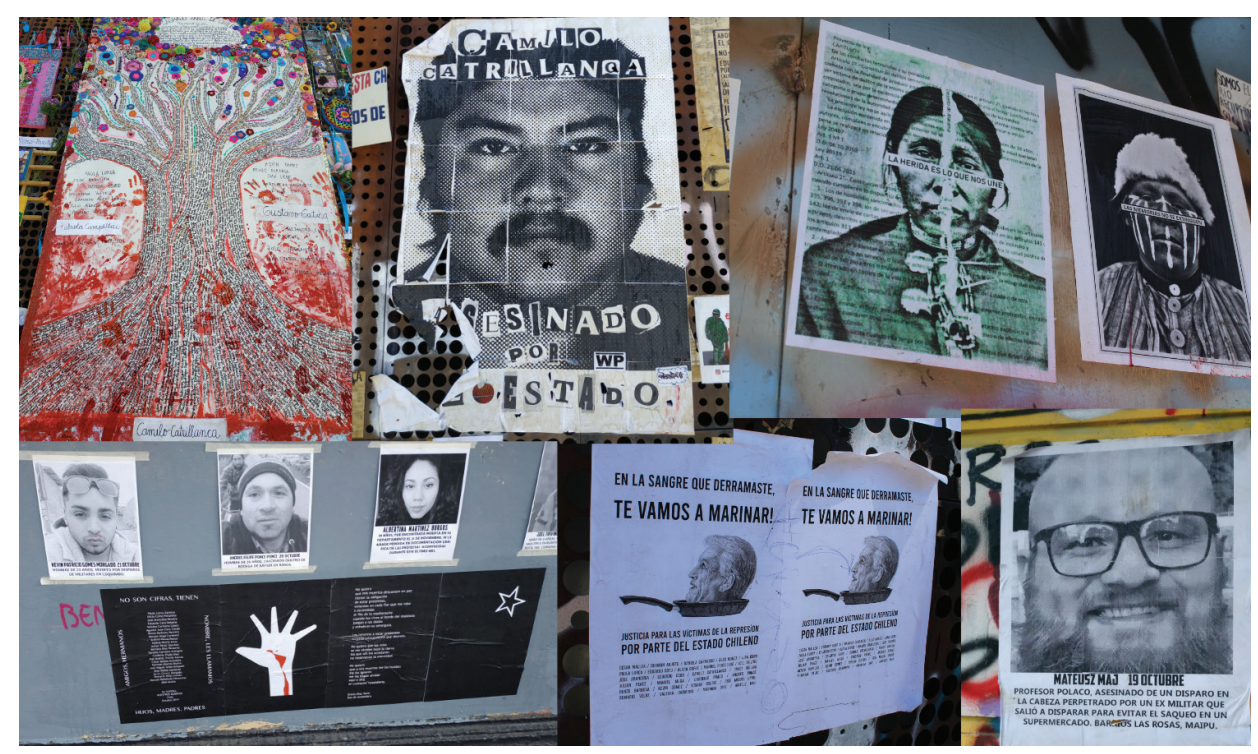

Ilustracja 3. Przykłady prac upamiętniających ofiary policyjnej represji i eksterminacji rdzennej ludności

Źródło: fotografie ułasne.

W kontekście upamiętniania analizowany materiał pozwala na uskazanie kilku kluczowych kodów wizualnych. Pieruszy odnosi się do rdzennej ludności Chile. Na kod ten składać się będzie flaga Mapuche i ilustracje bazujące na mapuchańskiej symbolice oraz postaciach. Podkreślać mają one wykluczenie i zbrodnie dokonywane na rdzennej ludności Chile. Wizerunkom Mapuche towarzyszą zuykle hasła: „pamięć nie uygasa” czy „rana jest tym, co nas łączy”, podkreślające brak rozliczenia bolesnej dla autochtonów historii i uregulowania ich praw, stanowiące jeden z powodów partycypacji w aktualnych protestach. Funkcję męczennika pełni w tym kontekście postać Camilo Catrillanci - rolnika, który zginął w niewyjaśnionych okolicznościach z rąk policyjnych antyterrorystów pod koniec 2018 roku w trakcie prac na suoim polu.

$\overline{88}$ B. Vogel i in., op. cit., s. 2154. 
Częsta zmiana zeznań i przebiegu akcji uzmocniła przekonania lokalnej społeczności, że było to celowe zabójstuo przedstawiciela zbuntowanej społeczności, który często wchodził w konflikt z policją ${ }^{89}$. Wizerunek Catrillanci był jednym z najczęściej występujących w analizowanym materiale. Męczennikami stały się również uszystkie ofiary aktualnych protestów. Galerie z ich zdjęciami i krótkim biogramami są rozwieszane w wielu miejscach Santiago. Symboliczną formą konstruowania polityki pamięci jest także adaptowanie historycznie ważnych dzieł sztuki, jak w przypadku pracy „Święte drzewo życia” autorstwa Helii Witker, która upamiętniać miała uszystkie zabite i „zaginione” ofiary reżimu Pinocheta. Zostało ono odtworzone przez protestujących uraz z dodaniem ofiar aktualnego „reżimu”. Podtrzymywana jest w ten sposób narracja „kontynuacji polityki” Pinocheta.

Ostatnim aspektem w kontekście upamiętnienia są treści muzyczne. Podobnie jak w komunistycznej Polsce, określone utwory stały się swoistymi protest songami, tak samo w Santiago są widoczne analogie. Z jednej strony w przestrzeni miejskiej pojawiały się teksty piosenek Victora Jary, chilijskiego piosenkarza i aktywisty politycznego, który został zamordowany przez reżim Pinocheta. Jego utwory są nie tylko wyrazem protestu względem władz, ale samo odwoływanie się i przywoływanie postaci Jary przekłada się na kultywowanie pamięci i męczeństwa uszystkich ofiar reżimu. Z drugiej strony treść piosenki „Un violador en tu camino” („Gwałciciel na Twojej drodze”) jest przejawem kreowania pamięci wszystkich kobiet padających ofiarami nie tylko przemocy, guałtów i dyskryminacji, z którymi spotykają się na co dzień, lecz także późniejszych działań policji, systemu sądownictwa i politycznych struktur władzy, które podtrzymują systematyczne łamanie praw kobiet ${ }^{90}$.

\section{Komunikowanie idei, wartości i reprezentacja}

Sztuka uliczna wykorzystująca przestrzeń miejską jako nieformalny kanał komunikacji stanowi zarówno narzędzie do generowania/konstruowania lokalnych/subkulturowych tożsamości, kuestionowania oficjalnych narracji, norm, wartości, jak i rolę medium demokratycznego umożliwiającego reprezentację określonych grup społecznych, problemów, stanowisk, idei, koncepcji pomijanych lub niedostatecznie reprezentowanych w oficjalnym dyskursie. Ta optyka pozwala na identyfikację szerszego katalogu problemów podnoszonych przez autorów, jak również stojących za nimi środowisk/organizacji. Analizy koncentrować się powinny na rozpoznaniu/dostrzeżeniu problemów, które u symbolicznej formie są odzwierciedlane w sztuce ulicznej w danych

\footnotetext{
${ }^{89}$ P. Nonnefoy, Killing of Indigenous Man in Chile Spurs Criticism of Security Forces, „The New York Times” 25.11.2018, https://wuw.nytimes.com/2018/11/25/world/americas/indigenous-killing-chile-land.html (dostęp: 8.04.2021).

${ }^{90}$ Ch. McGowan, Chilean anti-rape anthem becomes international feminist phenoomenon, „The Guardian”, https://www.theguardian.com/world/2019/dec/06/chilean-anti-rape-anthem-becomes-international-feminist-phenomenon (dostęp: 7.04.2021).
} 
okresach. Demokratyczny charakter sztuki ulicznej przekłada się bowiem na wielość autorów, a tym samym różnorodność tematyczną prac. W kontekście analiz street artu w okresach bez konfliktu ten aspekt może stanowić punkt wyjścia.

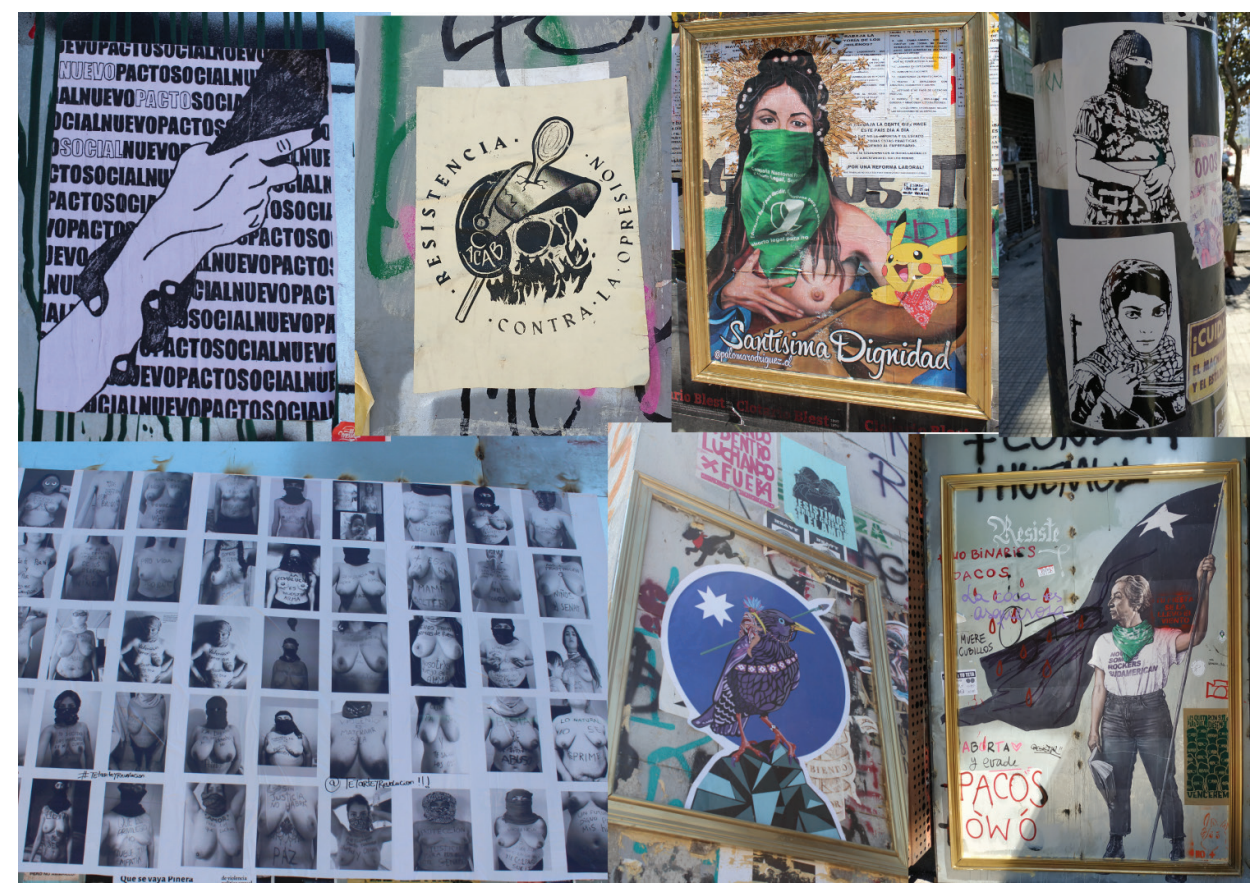

Ilustracja 4. Przykłady prac odnoszących się do komunikowanych idei, wartości, reprezentacji Źródło: fotografie ułasne.

Przyjmując te założenia $w$ analizowanym materiale $\mathrm{w}$ odniesieniu do reprezentacji w sposób uyraźny widać środowiska kobiece i feministyczne. Wprowadzają one, poza treściami odnoszącymi się do aktualnej sytuacji konfliktu (czynne zaangażowanie się kobiet w protesty, podkreślanie nadużyć policji wobec protestujących, w szczególności kobiet), również typowe dla tych środowisk problemy. Kluczowe kuestie to systemowa dyskryminacja kobiet i przemocy wobec nich (na co uskazywano wcześniej), walka o dostęp do darmowej i bezpiecznej aborcji i z patriarchatem oraz o zwiększenie udziału kobiet w życiu społeczno-politycznym. Poza warstwą tekstową, na poziomie kodów wizualnych treści feministyczne były wprowadzane z wykorzystaniem zielonych bandan, które stały się symbolem ruchu proaborcyjnego w Ameryce Łacińskiej oraz zdjęć i ilustracji przedstawiających postaci topless. Ciało jednocześnie jest uykorzystane jako przestrzeń do uyrażania kobiecych postulatów.

Obecność postaci i symboli charakterystycznych dla Mapucze to kolejny przejau reprezentacji, wizualne podkreślanie nie tylko ich obecności, zaangażowania, lecz także możliwość upominania się przez autochtonów o swoje prawa. W nieco mniejszym zakresie pojawiały się również treści wzywające do dyskusji nad nową konstytucją, 
a w szerszym zakresie konstrukcji nowego ładu społecznego, darmowego dostępu do edukacji. Aktualnie jedynie odpłatna edukacja przyczynia się do pogłębiania nierówności i społecznego uykluczania. W końcu widoczne były takie kwestie jak prawa zuierząt, promocja wegetarianizmu i weganizmu oraz ekologii, w szczególności ograniczenia destrukcyjnych działań korporacji.

\section{Podsumowanie}

Przedstawiona analiza pozwoliła pozytywnie zweryfikować zaproponowaną metodę badauczą pod kątem jej użyteczności w badaniach komunikacji. Bazując na korpusie zdjęć, uskazaliśmy, że - podążając obraną przez Vogela i innych drogą - możliwa jest rekonstrukcja narracji generowanej przez określone społeczności (w szczególności te marginalizowane, bez dostępu możliwości generowania treści w mediach głównego nurtu). W procesie analizy zidentyfikowano podstawowe problemy stanowiące źródło konfliktu i dominujących aktorów dyskursu. Wskazano róunież na katalog kluczowych dla protestujących idei i wartości oraz ważne historyczne postaci i wydarzenia stanowiące składniki pamięci historycznej danych grup. Pokazano róunież relacyjność sztuki ulicznej i poszczególnych składników przestrzeni miejskiej oraz jej roli w procesie wytuarzania określonej semantyki prac. Ponadto wykazano, że proponowana metoda jest możliwa do zastosowania niezależnie od wiedzy na temat danych społeczności. Przyjęcie perspektywy przygodnego obserwatora pozwoliło na rekonstrukcję tła wydarzeń w Chile z uwzględnieniem perspektywy protestujących. Rzecz jasna nie jest to wiedza kompletna i zapewne część naszych interpretacji jest dość fragmentarycznych. Jednakże pozyskany w wyniku analiz stan wiedzy stanowić może punkt wyjścia do dalszych, bardziej pogłębionych badań, uskazując na potencjalne istotne ścieżki dalszych eksploracji.

Uważamy zatem, że opisany proces badawczy jest narzędziem umożliwiającym pozyskanie dość kompleksowej wiedzy na temat społeczności, które - wykorzystując przestrzeń miejską jako kanał komunikacji - próbują dotrzeć do określonych audytoriów ze suoim przekazem za pośrednictwem różnorodnych form sztuki ulicznej. Przeprowadzona analiza ograniczyła się co prawda do materiału z obszaru aktywnego konfliktu. W dalszym ciągu potwierdzenia wymaga druga część naszych założeń odnośnie do uniwersalności metody badawczej, a mianowicie analiz sztuki ulicznej w okresach braku konfliktu. Stanowi to przedmiot naszych dalszych badań. Mamy jednak nadzieję, że zaadaptowanie tej metody $w$ badaniach komunikacji przełoży się na szerszy zakres badań nad graffiti i sztuką uliczną. 


\section{Bibliografia}

Armus T., "We are at war": 8 dead in Chile's violent protests over social inequality, „The Washington Post”, https://www.washingtonpost.com/nation/2019/10/21/chile-protests-santiago-dead-state-emergency/ (dostęp: 30.03.2021).

Baeza A., Evasión masiva de alumnos del Instituto Nacional en el Metro termina con denuncia en Fiscalía y medidas de contención, Latecera, https://www.latercera.com/nacional/noticia/ evasion-masiva-alumnos-del-instituto-nacional-metro-termina-denuncia-fiscalia-medidas-contencion/857409/ (dostęp: 6.04.2021).

Banco Mundial, PIB per cápita (US\$ a precios actuales) - Chile, https://datos.bancomundial. org/indicator/NY.GDP.PCAP.CD?locations=CL (dostęp: 6.04.2021).

Bartlett J., Chile students' mass fare-dodging expands into city-wide protest, „The Guardian”, https://www.theguardian.com/world/2019/oct/18/chile-students-mass-fare-dodging-expands-into-city-wide-protest (dostęp: 30.03.2021).

BBC Neus Mundo, Protestas en Chile: confirman la muerte de 15 personas mientras continúan los disturbios pese a que el gobierno suspendió el alza de las tarifas del metro en Santiago, BBC, https://wuw.bbc.com/mundo/noticias-america-latina-50112080 (dostęp: 30.03.2021).

Billig M., Banalny nacjonalizm, przeł. M. Sekerdej, Wydawnictwo Znak, Kraków 2008.

Bnamericas, Metro de Santiago: 80 estaciones danadas o destruidas durante protestas, https:// wuw.bnamericas.com/es/noticias/metro-de-santiago-80-estaciones-danadas-o-destruidas-durante-protestas (dostęp: 6.04.2021).

Bryła M., Sztuka ulicy jako bunt wobec zastanej rzeczywistości - anarchistyczna walka z systemem na przykładzie Polski, „Inskrypcje. Półrocznik” 2020, R. VIII, z. 1(14), s. 139-147.

Chabros C.E., Polskie graffiti lat osiemdziesiątych w świetle relacji jego twórców, „Pamięć i Sprawiedliwość" 2011, nr 10/1(17), s. 211-230.

Ciarka R., Napisy na murach i etnografia wspótczesnego miasta, „Polska Sztuka Ludowa” 1990, nr 2, s. 33-34.

Clarke J. i in., Subcultures, Cultures, and Class [w:] Resistance through Rituals, red. S. Hall, T. Jefferson, Routledge, London 1976.

De Berg H., Communication as Challenge to Systems Theory. „Canadian Review of Comparative Literature" 1997, s. 145-146.

Delgado M., Barton K., Murals in Latino Communities: Social Indicators of Community Strengths, „Social Work” 1998, t. 43, nr 4, s. 346-356.

El Desconcierto, Decretan inédito toque de queda en Santiago tras fracaso del gobierno en contener ola de protestas, https://wuw.eldesconcierto.cl/2019/10/19/decretan-inedito-toque-de-queda-en-santiago-tras-fracaso-del-gobierno-en-contener-ola-de-protestas/ (dostęp: 25.03.2021).

Fernanda P., Protestas en Chile: 4 claves para entender la furia y el estallido social en el país sudamericano, https://wuw.bbc.com/mundo/noticias-america-latina-50115798 (dostęp: 1.04.2021).

Ferrell J., Crimes of Style: Urban Graffiti and the Politics of Criminality, Northeastern University Press, Boston 1996.

Ferrell J., Urban Graffiti: Crime, Control, and Resistance, „Youth \& Society” 1995, nr 27(1), s. 73-92.

Fleischer M., Media w perspektywie konstruktywizmu, „2K - Kultura i Komunikacja” 2005, nr 1-2, s. 10-33. 
Franklin J., Chile protesters: „We are subjugated by the rich. It's time for that to end”, „The Guardian", https://www.theguardian.com/world/2019/oct/30/chile-protests-portraits-protesters-sebastian-pinera, (dostęp: 6.04.2021).

Frydrych W., Misztal B., Couderq A., Pomarańczowa Alternatywa: rewolucja Krasnoludków, Fundacja „Pomarańczowa Alternatywa”, Warszawa 2008.

González P., La desigualdad que despertó a Chile, https://radio.uchile.cl/2019/10/28/ la-desigualdad-que-desperto-a-chile/ (dostęp: 30.03.2021).

Grotouska S., „Street Art” i „Guerilla Marketing” jako próby tworzenia przestrzeni publicznej, „Studia Humanistyczne AGH” 2012, nr 11(3), s. 11-24.

Gugler J., The Urban Character of Contemporary Revolutions, „Studies in Comparative International Development" 1982, t. 17, nr 2, s. 62-69.

Halsey M., Young A., The meanings of graffiti and municipal administration, „Australian \& New Zealand Journal of Criminology" 2002, vol. 35(2), s. 165-186.

Hansen S., Danny F., «This is not a Banksy!»: street art as aesthetic protest, „Continuum” 2015, nr 29(6), s. 899.

Jenkins H., Kultura konwergencji. Zderzenie starych i nowych mediów, przeł. M. Bernatowicz, M. Filiciak, Wydaunictwa Akademickie i Profesjonalne, Warszawa 2007.

Kaczmarska M., Graffiti kontra murale. Intencje twórcy a recepcja społeczna sztuki ulicznej [w:] Ulice, Centra, Peryferie, red. S. Hryń, D. Juruś, Oficyna Wydawnicza AFM, Kraków 2017, s. 37-52.

Konstruktywizm w badaniach literackich. Antologia, red. E. Kuźma, A. Skrendo, J. Madejski, Towarzystwo Autorów i Wydawców Prac Naukowych Universitas, Kraków 2006.

Kowaleuski M., Miasto jako arena protestu, „Konteksty Społeczne” 2013, nr 1, s. 18-24.

Kowaleuski M., Protest miejski. Przestrzenie, tożsamości i praktyki niezadowolonych obywateli miast, NOMOS, Kraków 2016.

Lachouska K., Pielużek M., Miasto jako przestrzeń ideologiczna - analiza sztuki ulicznej towarzyszacej aktualnym protestom w Chile, „Annales Universitatis Paedagogicae Cracoviensis. Studia de Cultura" 2020, nr 12(2), s. 93-121.

Laszlo E., Systemowy obraz świata, przeł. U. Niklas, Państwowy Instytut Wydauniczy, Warszawa 1978.

Leszek M., Mural jako forma plastyczna w przestrzeni architektonicznej i urbanistycznej Meksyku, „Architectus” 2019, nr 3(59), s. 41-56.

Lewisohn A.S., Mexican Murals and Diego Rivera, „Parnassus” 1935, t. 7, nr 7, s. 11-12.

Luhmann N., Systemy społeczne: zarys ogólnej teorii, przeł. M. Kaczmarczyk, Zakład Wydawniczy Nomos, Kraków 2007.

Mańko R., Koncepcja interpelacji ideologicznej a krytyczny dyskurs o prawie, „Archiwum Filozofii Prawa i Filozofii Społecznej" 2014, nr 1, s. 45.

Maturana H., Ontologia obserwacji. Biologiczne podstawy samoświadomości i fizykalna dziedzina egzystencji [w:] Radykalny konstruktywizm. Antologia, red. B. Balicki i in., Wydawnictuo Gajt, Wrocław 2010.

Mazzini M., Protesty $w$ Chile. Największe od upadku dyktatury Pinocheta, Polityka, https:// wuw.polityka.pl/tygodnikpolityka/swiat/1929856,1,protesty-w-chile-najwieksze-od-upadku-dyktatury-pinocheta (dostęp: 30.03.2021).

McGowan Ch., Chilean anti-rape anthem becomes international feminist phenomenon, „The Guardian”, https://www.theguardian.com/world/2019/dec/06/chilean-anti-rape-anthem-becomes-international-feminist-phenomenon (dostęp: 7.04.2021). 
Miladi N., Alternative fabrics of hegemony: City squares and street graffiti as sites of resistance and interactive communication flow, ,Journal of African Media Studies” 2015, nr 7, s. 134.

Mirzoeff N., Jak zobaczyć świat, przeł. Ł. Zaremba, Wydawnictwo Karakter, Kraków-Warszawa 2016.

Mitchell D., The Right to the City: Social Justice and the Fight for Public Space, Guilford Press, New York 2003.

Molina P., Estado de emergencia en Chile: la jornada de protestas en Santiago que llevó al presidente Pinera a suspender el alza del precio del metro, BBC, https://wuw.bbc.com/ mundo/noticias-america-latina-50112071 (dostęp: 6.04.2021).

Niemczyk A., Paliś B., Mural jako narzędzie promocji turystycznej miasta, „Przedsiębiorczość i Zarządzanie" 2017, T. XVIII, z. 8, cz. III, s. 169-181.

Nonnefoy P., Killing of Indigenous Man in Chile Spurs Criticism of Security Forces, „The New York Times" 25.11.2018, https:/www.nytimes.com/2018/11/25/world/americas/ indigenous-killing-chile-land.html (dostęp: 8.04.2021).

Nowak M., Byli wzorem dla Polski, tona w narodowym chaosie. W Chile 17 zabitych i tysiace aresztowanych, OKO Press, https://oko.press/byli-wzorem-dla-polski-tona-w-narodowymchaosie-w-chile-17-zabitych-i-tysiace-aresztowanych/ (dostęp: 6.04.2021).

Ortiz van Meerbeke G., Sletto B., Graffiti takes its own space, „City: analysis of urban trends, culture, theory, policy, action" 2019, nr 23(3), s. 366-387.

Paliś B., Mural jako środek w kreowaniu wizerunku przestrzeni miejskiej [w:] Czy obrazy rządzą ludźmi, red. A. Kampka, A. Kiryjow, K. Sobczak, Wydawnictwo SGGW, Warszawa 2017, s. 102-116.

Park E.R., On Social Control and Collective Behavior, The University of Chicago Press, Chicago 1967.

Piękoś M., W Chile podział na lepszych i gorszych jest nie tylko ekonomiczny, ale też rasowy, „Krytyka Polityczna”, https://krytykapolityczna.pl/suiat/zamieszki-w-chile-michal-piekos/ (dostęp: 6.04.2021).

Radykalny konstruktywizm. Antologia, red. B. Balicki [i in.], Wydawnictwo Gajt, Wrocław 2010.

Rolston B, jHasta La Victoria!: Murals and Resistance in Santiago, Chile, „Identities” 2011, nr 18(2), s. 113-114.

Schmidt J.S., Konstruktywizm jako teoria mediów [w:] Konstruktywizm w badaniach literackich. Antologia, red. E. Kuźma, A. Skrendo, J. Madejski, Towarzystuo Autorów i Wydawców Prac Naukouych Universitas, Kraków 2006.

Schmidt J.S., Kultura a kontyngencja: nauki obserwatora, „2К - Kultura i Komunikacja” 2004, nr 1, s. 2-5.

Sehnbruch K., How Pinochet's economic model led to the current crisis engulfing Chile, https:// www.theguardian.com/world/2019/oct/30/pinochet-economic-model-current-crisis-chile (dostęp: 1.04.2021).

Sozański T., Sieć społeczna [w:] Encyklopedia socjologii PWN, Wydawnictuo Naukoue PWN, Warszawa 2002.

Statucki M., Jak badać murale z perspektywy socjologicznej? Przykład Łodzi, „Człowiek i Społeczeństwo" 2009, t. XLVIII, s. 107-122.

Sturken M., Cartwright L., Practoces of Looking. An Introduction to Visual Culture, Oxford University Press, New York-Oxford 2001. 
Taylor V., Van Dyke N., „Get up, Stand up”: Tactical Repertoires of Social Movements [w:] The Blackwell Companion to Social Movements, ed. D.A. Snow, S.A. Soule, H. Kriesi, Blackwell Publishing Ltd, Hoboken 2004, s. 262-292.

Tendera M., Protest jako mechanizm równoważenia nierówności społecznych, „Kultura i Społeczeństwo" 2013, nr 2, s. 111-132.

The Santiago Times, Chile's University Tuition Fees amongst world's highest, https://santiagotimes.cl/2017/09/15/chiles-university-tuition-fees-amongst-worlds-highest/ (dostęp: 1.04.2021).

United Nations, Raport of the Mission to Chile 30 October - 22 November 2019, https://www. ohchr.org/Documents/Countries/CL/Report_Chile_2019_EN.pdf (dostęp: 6.04.2021).

United Nations. UN human rights report cites 'multiple root causes' of deadly Chile protests, 2019, https://news.un.org/en/story/2019/12/1053491 (dostęp: 8.04.2021).

Vogel B., Arthur C., Leppb E., O'Driscollc D., Haworth T.B., Reading socio-political and spatial dynamics through graffiti in conflict-affected societies, „Third World Quarterly” 2020, t. 41, nr 12, s. 2148-2168.

Walczouska K., Goraca sytuacja w Chile nie ustaje. Polka ttumaczy, czego chca obywatele, Onet, https://podroze.onet.pl/aktualnosci/protesty-w-chile-polka-tlumaczy-przyczyne-santiago-zycie-w-chile/z54mpw2 (dostęp: 25.03.2021).

Wallis A., Socjologia przestrzeni, przeł. I. Drozdouska-Broering, Niezależna Oficyna Wydawnicza, Warszawa 1990. 